Waste Site Reclassification Form

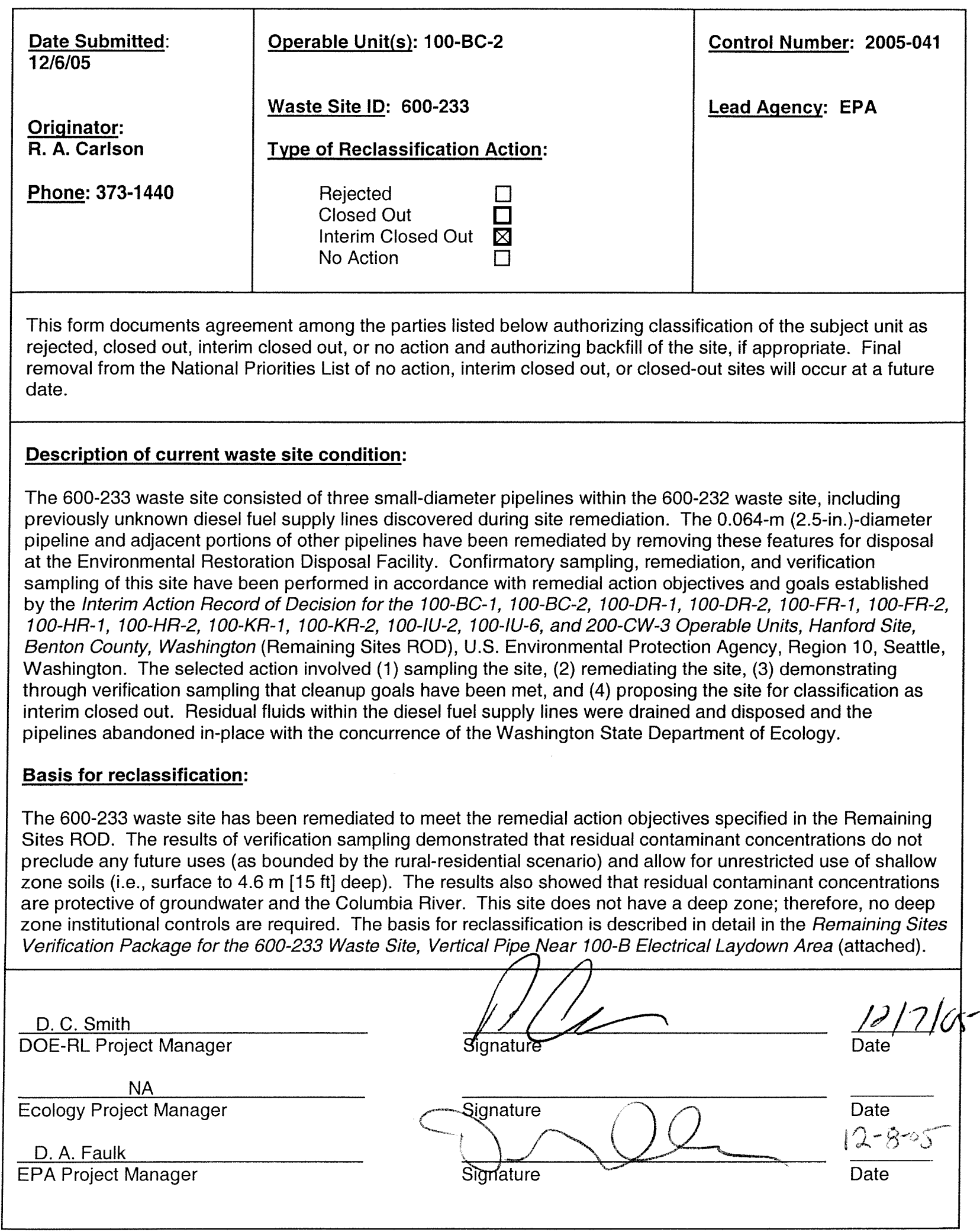


REMAINING SITES VERIFICATION PACKAGE FOR THE 600-233 WASTE SITE, VERTICAL PIPE NEAR 100-B ELECTRICAL LAYDOWN AREA

Attachment to Waste Site Reclassification Form 2005-041

December 2005 


\section{REMAINING SITES VERIFICATION PACKAGE FOR THE 600-233 WASTE SITE, VERTICAL PIPE NEAR 100-B ELECTRICAL LAYDOWN AREA}

\section{EXECUTIVE SUMMARY}

The 600-233 waste site, part of the 100-BC-2 Operable Unit, consisted of three small-diameter pipelines located within the 600-232 waste site (100-B Electrical Laydown Yard), including a $0.064-\mathrm{m}(2.5$-in.) steel pipe extending approximately $1.5 \mathrm{~m}(4.9 \mathrm{ft})$ vertically from the ground surface. In the Waste Information Data System, it is postulated that the pipelines were an extension of the fire control system that serviced the laydown yard, and the status of the site was listed as "rejected." Following the detection of metals at levels exceeding remedial action goals in a sample collected from the vertical pipe during field activities at the 600-232 waste site, the status was changed to "inactive" and remedial actions were initiated.

During remedial activities and exploratory excavations, two small-diameter pipe segments were discovered in the site vicinity. Residual liquids within these pipelines were drained and characterized for disposal and the pipelines subsequently determined to have been used for diesel fuel supply. It was decided that the discovery pipelines posed no adverse risk to human health or the environment and could be abandoned in place (Appendix E).

Remediation of the 600-233 waste site consisted of the removal of the $0.064-\mathrm{m}$ (2.5-in.) steel pipeline via excavation of a $23-\mathrm{m}(75-\mathrm{ft})-$ long by $0.5-\mathrm{m}(1.6-\mathrm{ft})$-deep trench. The eastern end of the pipeline was discovered to terminate with a pipe cap, and the pipeline was removed for disposal at the Environmental Restoration Disposal Facility. No radiation was detected above background levels during excavation, and no staining or anomalous materials were observed.

Following remediation, verification sampling was conducted on August 9, 2005. The results indicated that the waste removal action achieved compliance with the remedial action objectives for the 600-233 site. A summary of the verification sampling evaluation for the soil results compared against the applicable criteria is presented in Table ES-1. The results of the verification sampling are used to make reclassification decisions for the 600-233 site in accordance with the TPA-MP-14 (DOE-RL 1998) process.

In accordance with this evaluation, the confirmatory sampling results support a reclassification of this site to interim closed out. The current site conditions achieve the remedial action objectives and the corresponding remedial action goals established in the Remedial Design Report/Remedial Action Work Plan for the 100 Area (DOE-RL 2005b) and the Interim Action Record of Decision for the 100-BC-1, 100-BC-2, 100-DR-1, 100-DR-2, 100-FR-1, 100-FR-2, 100-HR-1, 100-HR-2, 100-KR-1, 100-KR-2, 100-IU-2, 100-IU-6, and 200-CW-3 Operable Units, Hanford Site, Benton County, Washington (EPA 1999). The results of verification sampling show that residual contaminant concentrations do not preclude any future uses (as bounded by the rural-residential scenario) and allow for unrestricted use of shallow zone soils (i.e., surface to $4.6 \mathrm{~m}[15 \mathrm{ft}]$ deep). The results also demonstrate that residual contaminant concentrations are protective of groundwater and the Columbia River. This site does not have a deep zone; therefore, no deep zone institutional controls are required. 
Table ES-1. Summary of Remedial Action Goals for the 600-233 Site. (2 Pages)

\begin{tabular}{|c|c|c|c|}
\hline $\begin{array}{l}\text { Regulatory } \\
\text { Requirement }\end{array}$ & Remedial Action Goals & Results & $\begin{array}{l}\text { Remedial Action } \\
\text { Objectives } \\
\text { Attained? }\end{array}$ \\
\hline $\begin{array}{l}\text { Direct Exposure - } \\
\text { Radionuclides }\end{array}$ & $\begin{array}{l}\text { Attain } 15-\mathrm{mrem} / \mathrm{yr} \text { dose rate above } \\
\text { background over } 1,000 \text { years. }\end{array}$ & $\begin{array}{l}\text { No radionuclide } \mathrm{COCs} / \mathrm{COPCs} \text { were } \\
\text { identified for this site. }\end{array}$ & N/A \\
\hline $\begin{array}{l}\text { Direct Exposure - } \\
\text { Nonradionuclides }\end{array}$ & $\begin{array}{l}\text { Attain individual } \mathrm{COC} / \mathrm{COPC} \\
\text { RAGs. }\end{array}$ & $\begin{array}{l}\text { All individual } \mathrm{COC} / \mathrm{COPC} \\
\text { concentrations are below the direct } \\
\text { exposure criteria. }\end{array}$ & Yes \\
\hline \multirow[t]{4}{*}{$\begin{array}{l}\text { Risk Requirements - } \\
\text { Nonradionuclides }\end{array}$} & $\begin{array}{l}\text { Attain a hazard quotient of }<1 \text { for } \\
\text { all individual noncarcinogens. }\end{array}$ & $\begin{array}{l}\text { All individual hazard quotients are } \\
\text { less than } 1 .\end{array}$ & \multirow{4}{*}{ Yes } \\
\hline & $\begin{array}{l}\text { Attain a cumulative hazard } \\
\text { quotient of }<1 \text { for noncarcinogens. }\end{array}$ & $\begin{array}{l}\text { The cumulative hazard quotient }(8.0 \times \\
\left.10^{-3}\right) \text { is less than } 1 .\end{array}$ & \\
\hline & $\begin{array}{l}\text { Attain an excess cancer risk of } \\
<1 \times 10^{-6} \text { for individual } \\
\text { carcinogens. }\end{array}$ & $\begin{array}{l}\text { The excess cancer risk values for } \\
\text { carcinogens are less than } 1 \times 10^{-6} \text {. }\end{array}$ & \\
\hline & $\begin{array}{l}\text { Attain a cumulative excess cancer } \\
\text { risk of }<1 \times 10^{-5} \text { for carcinogens. }\end{array}$ & $\begin{array}{l}\text { The total excess cancer risk } \\
\left(2.2 \times 10^{-6}\right) \text { is less than } 1 \times 10^{-5} \text {. }\end{array}$ & \\
\hline \multirow{4}{*}{$\begin{array}{l}\text { Groundwater/River } \\
\text { Protection - } \\
\text { Radionuclides }\end{array}$} & $\begin{array}{l}\text { Attain single-COPC groundwater } \\
\text { and river protection RAGs. }\end{array}$ & \multirow{4}{*}{$\begin{array}{l}\text { No radionuclide } \mathrm{COCs} / \mathrm{COPCs} \text { were } \\
\text { identified for this site. }\end{array}$} & \multirow{4}{*}{ N/A } \\
\hline & $\begin{array}{l}\text { Attain national primary drinking } \\
\text { water standards: } 4 \text { mrem/yr } \\
\text { (beta/gamma) dose rate to target } \\
\text { receptor/organs. }\end{array}$ & & \\
\hline & $\begin{array}{l}\text { Meet drinking water standards for } \\
\text { alpha emitters: the most stringent } \\
\text { of } 15 \mathrm{pCi} / \mathrm{L} \text { MCL or } 1 / 25^{\text {th }} \text { of the } \\
\text { derived concentration guides from } \\
\text { DOE Order } 5400.5^{\text {b }}\end{array}$ & & \\
\hline & $\begin{array}{l}\text { Meet total uranium standard of } \\
30 \mu \mathrm{g} / \mathrm{L}(21.2 \mathrm{pCi} / \mathrm{L})^{c}\end{array}$ & & \\
\hline $\begin{array}{l}\text { Groundwater/River } \\
\text { Protection - } \\
\text { Nonradionuclides }\end{array}$ & $\begin{array}{l}\text { Attain individual nonradionuclide } \\
\text { groundwater and river cleanup } \\
\text { requirements. }\end{array}$ & $\begin{array}{l}\text { Maximum detected results for } \\
\text { selenium and chrysene are above soil } \\
\text { RAGs for river protection. However, } \\
\text { results of the } 100 \text { Area Analogous } \\
\text { Sites RESRAD Calculations (BHI } \\
2005 \text { a) indicate that these constituents } \\
\text { will not reach groundwater (and } \\
\text { therefore the Columbia River) within } \\
1,000 \text { years. Therefore, their residual } \\
\text { concentrations achieve the RAOs for } \\
\text { river protection. }\end{array}$ & Yes \\
\hline
\end{tabular}


Table ES-1. Summary of Remedial Action Goals for the 600-233 Site. (2 Pages)

\begin{tabular}{|c|c|c|c|}
\hline $\begin{array}{c}\text { Regulatory } \\
\text { Requirement }\end{array}$ & Remedial Action Goals & Results & $\begin{array}{c}\text { Remedial Action } \\
\text { Objectives } \\
\text { Attained? }\end{array}$ \\
\hline
\end{tabular}

a "National Primary Drinking Water Regulations" (40 Code of Federal Regulations 141).

${ }^{\mathrm{b}}$ Radiation Protection of the Public and the Environment (DOE Order 5400.5).

${ }^{c}$ Based on the isotopic distribution of uranium in the 100 Areas, the $30 \mu \mathrm{g} / \mathrm{L} \mathrm{MCL}$ corresponds to $21.1 \mathrm{pCi} / \mathrm{L}$. Concentration-toactivity calculations are documented in Calculation of Total Uranium Activity Corresponding to a Maximum Contaminant Level for Total Uranium of 30 Micrograms per Liter in Groundwater (BHI 2001).

COC = contaminant of concern

$\mathrm{COPC}=$ contaminant of potential concern

$\mathrm{MCL}=$ maximum contaminant level

N/A $=$ not applicable

RAG = remedial action goal

RAO = remedial action objective 


\section{REMAINING SITES VERIFICATION PACKAGE FOR THE 600-233 WASTE SITE, VERTICAL PIPE NEAR 100-B ELECTRICAL LAYDOWN AREA}

\section{STATEMENT OF PROTECTIVENESS}

This report demonstrates that the 600-233 waste site meets the objectives for interim closure as established in the Remedial Design Report/Remedial Action Work Plan for the 100 Area (RDR/RAWP) (DOE-RL 2005b) and the Interim Action Record of Decision for the 100-BC-1, 100-BC-2, 100-DR-1, 100-DR-2, 100-FR-1, 100-FR-2, 100-HR-1, 100-HR-2, 100-KR-1, 100-KR-2, 100-IU-2, 100-IU-6, and 200-CW-3 Operable Units, Hanford Site, Benton County, Washington (Remaining Sites ROD) (EPA 1999). The results of verification sampling show that residual contaminant concentrations do not preclude any future uses (as bounded by the ruralresidential scenario) and allow for unrestricted use of shallow zone soils (i.e., surface to $4.6 \mathrm{~m}$ [15 ft] deep). The results also demonstrate that residual contaminant concentrations are protective of groundwater and the Columbia River. This site does not have a deep zone; therefore, no deep zone institutional controls are required.

\section{GENERAL SITE INFORMATION AND BACKGROUND}

The 600-233 waste site, part of the 100-BC-2 Operable Unit, is located within the 600-232 waste site (100-B Electrical Laydown Yard) on the northern side of the railroad tracks (Figure 1). The area is approximately $250 \mathrm{~m}(820 \mathrm{ft})$ southeast of the 105-C Reactor Building, outside of the exclusion fence. The 600-233 waste site was a $0.064-\mathrm{m}$ (2.5-in.)-diameter steel pipe extending approximately $1.5 \mathrm{~m}(4.9 \mathrm{ft})$ vertically from the ground surface with an elbow and valve at the top. A historical photograph of the vertical pipe is included in Appendix A. The Waste Information Data System (WIDS) also reports a 0.019-m (0.75-in.) steel pipe located approximately $20 \mathrm{~m}$ ( $66 \mathrm{ft}$ ) east of the vertical pipe. Documentation of pipelines in the area could not be found in historical drawings, and no facilities are known to have existed in the area other than the railroad and electrical laydown yard. In the WIDS, it is postulated that the pipelines were an extension of the fire control system that serviced the 100-B Electrical Laydown Yard (600-232 waste site), and the status of the site was listed as "rejected." Following the detection of metals at levels exceeding remedial action goals (RAGs) in a sample collected from the vertical pipe during field activities at the 600-232 waste site, the status was changed to "inactive" and remedial actions were initiated.

During remedial activities and exploratory excavations, a $0.025-\mathrm{m}(1-\mathrm{in}$.) pipe segment and a $0.019-\mathrm{m}(0.75$-in.) steel pipe were also discovered in the site vicinity, generally laying perpendicular to the $0.064-\mathrm{m}$ (2.5-in.) pipe. These discovered pipelines contained residual liquids that were drained and characterized for disposal and subsequently determined to have been used for diesel fuel supply unrelated to the vertical pipe. It was decided that the discovery pipelines posed no adverse risk to human health or the environment and could be abandoned in place (Appendix E). 
Figure 1. Location of the 600-233 Waste Site.

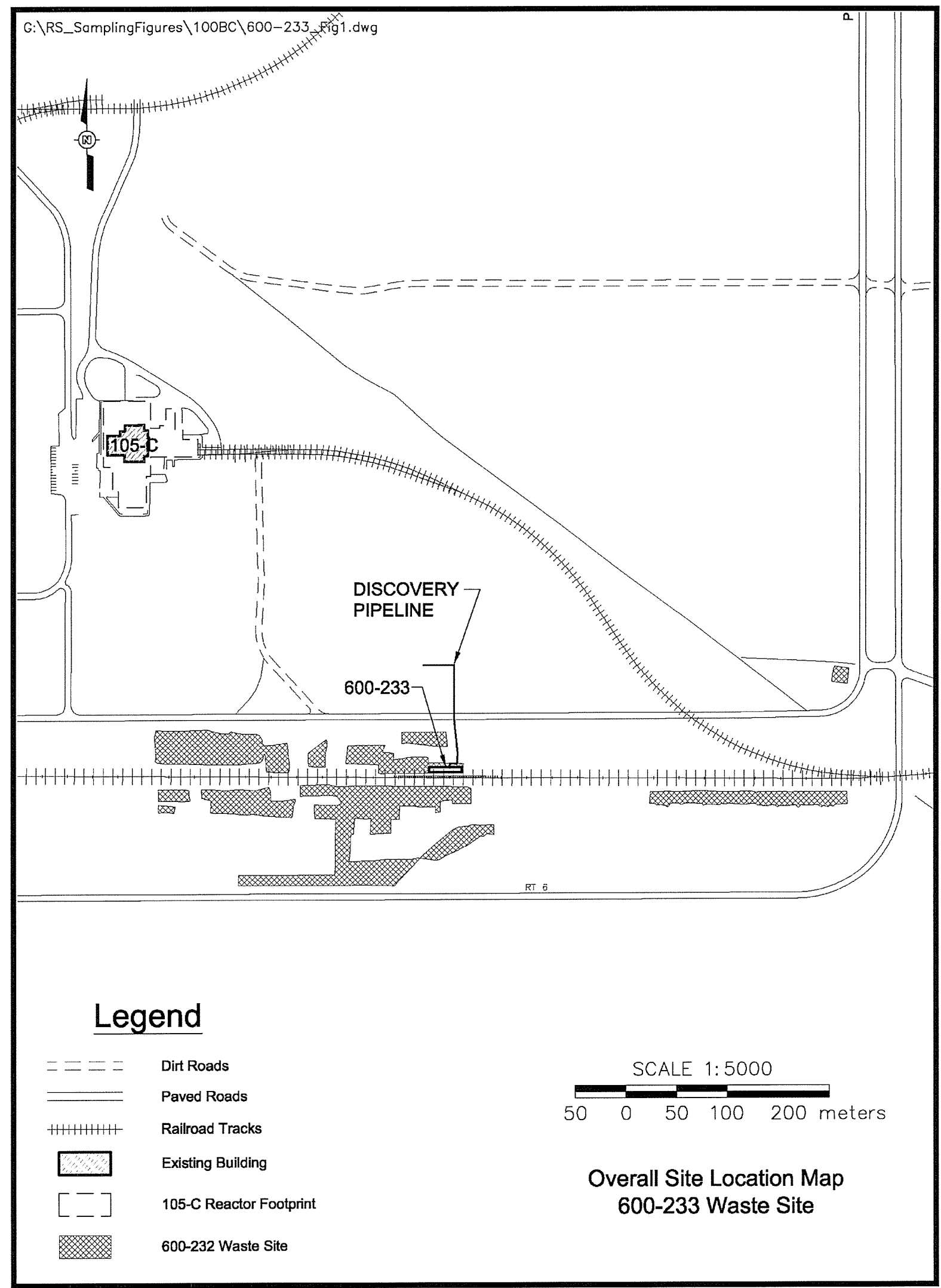




\section{CONFIRMATORY SAMPLING ACTIVITIES}

Confirmatory sampling of the 600-233 waste site was performed during May 2004 to collect information to support evaluation of the site against the RAGs and objectives (RAOs) established by the Remaining Sites ROD (EPA 1999). Based on the results of this confirmatory sampling, it was determined that remedial action was necessary at the site (DOE-RL and EPA 2004). The following subsections provide additional discussion of available site information and the results of the confirmatory sampling activities.

\section{Site Geophysical Survey Information}

A geophysical survey was performed at the 600-232 and 600-233 waste sites in August 2003 using ground-penetrating radar and magnetometry (Bergstrom and Mitchell 2003). The survey identified subsurface linear anomalies as shown in Figure 2, but no other anomalous features of note.

\section{Confirmatory Sample Results}

Following remediation of the surrounding 600-232 waste site, a scale sample (J01FT9) was collected from the vertical pipe at the 600-233 waste site by excavating and unthreading the pipe (BHI 2003). Arsenic $(22.7 \mathrm{mg} / \mathrm{kg})$ and lead $(7,730 \mathrm{mg} / \mathrm{kg})$ were detected in this sample at levels exceeding direct exposure RAGs. Cadmium $(2.3 \mathrm{mg} / \mathrm{kg})$, chromium $(55.7 \mathrm{mg} / \mathrm{kg})$, and aroclor- $1260(0.12 \mathrm{mg} / \mathrm{kg})$ were also detected at levels exceeding groundwater and river protection RAGs. Based on these results, it was determined that remedial action was necessary at the 600-233 waste site. Complete analytical results for the confirmatory sample are provided in Appendix B (Table B-1).

\section{REMEDIAL ACTION SUMMARY}

Remediation of the 600-233 waste site consisted of the removal of the $0.064-\mathrm{m}$ (2.5-in.) steel pipeline via excavation of a $23-\mathrm{m}$ ( $75-\mathrm{ft})$-long by $0.5-\mathrm{m}$ (1.6-ft)-deep trench. The eastern end of the pipeline was discovered to terminate with a pipe cap, and the pipeline was removed for disposal at the Environmental Restoration Disposal Facility. No radiation was detected above background levels during excavation, and no staining or anomalous materials were observed. During remediation, waste characterization samples were collected from pipe scale, suspect water within the pipeline, and soils impacted by the suspect water. The analytical results for these samples are provided in Appendix B (Table B-2).

During excavation of the primary $0.064-\mathrm{m}$ (2.5-in.) pipeline, two small-diameter $(0.019 \mathrm{~m}$ [0.75 in.] and $0.025 \mathrm{~m}$ [1 in.]) pipelines were uncovered at the eastern end of the trench. Analysis of the liquid collected from one of the lines confirmed that the liquid was weathered diesel fuel. Using pipeline-locating equipment, pipelines were identified trending north from the 
Figure 2. Interpreted Results of the Geophysical Survey at the 600-233 Waste Site.

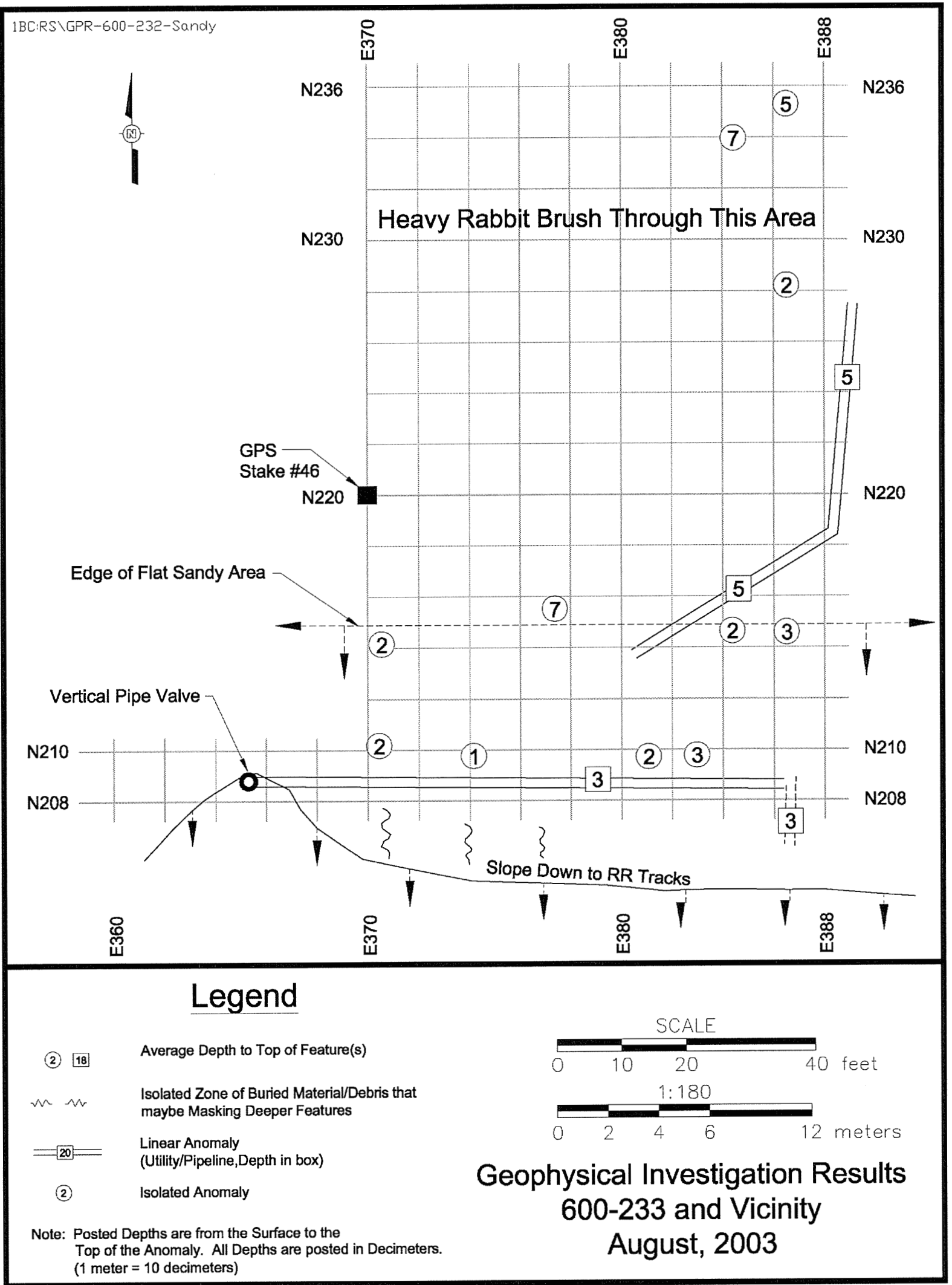


trench for approximately $73 \mathrm{~m}(240 \mathrm{ft})$ before turning west and extending for approximately $55 \mathrm{~m}(180 \mathrm{ft})$. All liquids present in these pipelines were drained and containerized for sampling and disposal. The results of in-process samples collected from these pipelines and underlying soils are provided in Appendix B (Table B-2).

Based on the determination that these discovered pipelines were historically used for diesel fuel supply, it was decided that the residual piping posed no adverse risk to human health or the environment and could be abandoned in place (Appendix E). A post-excavation civil survey of the 600-233 pipeline, including the location of the abandoned discovery pipelines, is provided in Figure 3.

\section{VERIFICATION SAMPLING ACTIVITIES}

Verification sampling for the 600-233 site was performed on August 9, 2005, to collect data to make a decision as to whether the RAOs had been reached. Based on the evaluation of the resulting data, the residual contaminant concentrations meet the cleanup criteria specified in the RDR/RAWP (DOE-RL 2005b) and the Remaining Sites ROD (EPA 1999). The following subsections provide additional discussion of the information used to develop the verification sampling design. The results of the verification sampling are also summarized to support interim closure of the site.

\section{Contaminants of Concern and Contaminants of Potential Concern}

The results of confirmatory and waste characterization sampling at the 600-232 and 600-233 waste sites were used to determine the contaminants of concern (COCs) and contaminants of potential concern (COPCs) for verification sampling. The COCs include the constituents that were detected above direct exposure RAGs at the 600-233 waste site and are listed in Table 1. Those constituents that were detected above groundwater and/or river protection RAGs during confirmatory sampling, but were not predicted to migrate to groundwater based on the 100 Area Analogous Sites RESRAD Calculations (BHI 2005a), were carried forward as COPCs for verification sampling. Due to RAG exceedances at the 600-232 waste site (DOE-RL and EPA 2004), semivolatile organic compounds (SVOCs) and nickel were also included as COPCs for verification sampling. While not considered COCs or COPCs, metals from the expanded list of inductively coupled plasma (ICP) metals (antimony, beryllium, boron, cobalt, copper, manganese, molybdenum, vanadium, and zinc) were also included in the requested laboratory analyses due to their absence from previous sampling events. 
Figure 3. Post-Excavation Survey of the 600-233 Waste Site and Verification Sampling Locations.

G: \RS_SamplingFigures $\backslash 100 B C \backslash 600-233$ Fig3.dwg

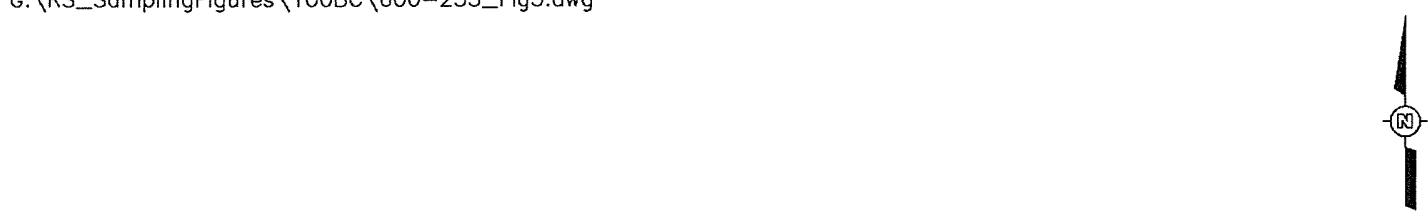

\section{PERIMETER ROAD}

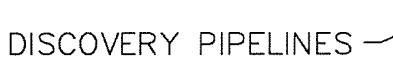

EXCAVATED

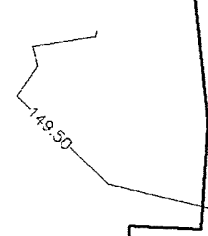

J03WJ2

J03WJ1

J03WJ3

$\nabla$

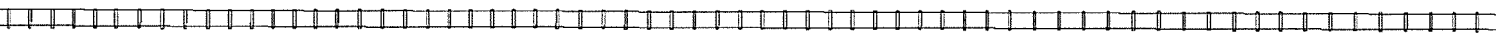

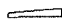

Legend

प\| Railroad Tracks
SCALE 1:800

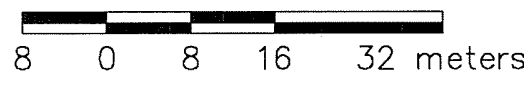

600-233 Waste Site Verification Sampling Locations 
Table 1. Contaminants of Concern and Contaminants of Potential Concern for Verification Sampling at the 600-233 Waste Site.

\begin{tabular}{|c|c|}
\hline Contaminants of Concern & Contaminants of Potential Concern \\
\hline Arsenic & Cadmium \\
\hline Lead & Chromium \\
\hline TPH & PCBs \\
\hline & SVOCs \\
\hline & Nickel \\
\hline
\end{tabular}

$\mathrm{PCB}=$ polychlorinated biphenyl

SVOC = semivolatile organic compound

$\mathrm{TPH}=$ total petroleum hydrocarbon

\section{Verification Sampling Design}

As described in the Work Instruction for Verification Sampling of the 600-233 Waste Site, Vertical Pipe Near 100-B Electrical Laydown Area (BHI 2005c), a focused verification sampling strategy was used because the former location of the $0.064-\mathrm{m}$ (2.5-in.) pipeline was known and assumptions could be made about the most probable locations of potential residual contamination. Two soil sample locations were identified for verification sampling as shown in Figure 3. These locations were selected as points underlying the former above-grade vertical pipe and the opposite end of the pipe. One soil sample was taken at each location by collecting 15 aliquots from soils at the excavation floor within $1 \mathrm{~m}(3 \mathrm{ft})$ of the designated sample point and combining into one sample. One duplicate soil sample was also collected at the western sample location beneath the former above-grade portion of the pipeline. One equipment blank sample consisting of clean silica sand poured over sampling equipment was collected and analyzed for ICP metals and SVOCs. A summary of the samples collected during verification sampling and the analysis performed is presented in Table 2. All sampling was performed in accordance with BHI-EE-01, Environmental Investigations Procedures.

Table 2. Verification Sample Summary Table. (2 Pages)

\begin{tabular}{|c|c|c|c|c|c|}
\hline Sample Location & $\begin{array}{l}\text { Sample } \\
\text { Media }\end{array}$ & $\begin{array}{c}\text { HEIS } \\
\text { Number }\end{array}$ & $\begin{array}{c}\text { Sample } \\
\text { Coordinates }\end{array}$ & Depth & Sample Analyses \\
\hline $\begin{array}{l}\text { Western end of trench } \\
\text { (beneath former vertical } \\
\text { pipe) }\end{array}$ & Soil & J03WJ2 & $\begin{array}{l}\text { N } 143690 \mathrm{~m} \\
\text { E } 565663 \mathrm{~m}\end{array}$ & $\begin{array}{c}\text { Base of trench } \\
\text { (approximately } \\
0.5 \mathrm{~m}[1.6 \mathrm{ft}] \mathrm{bgs})\end{array}$ & $\begin{array}{l}\text { ICP metals, }{ }^{a} \text { PCB, SVOA, } \\
\text { and TPH }\end{array}$ \\
\hline $\begin{array}{l}\text { Eastern end of trench } \\
\text { (beneath former pipe cap) }\end{array}$ & Soil & J03WJ1 & $\begin{array}{l}\text { N } 143690 \mathrm{~m} \\
\text { E } 565683 \mathrm{~m}\end{array}$ & $\begin{array}{c}\text { Base of trench } \\
\text { (approximately } \\
0.5 \mathrm{~m}[1.6 \mathrm{ft}] \mathrm{bgs})\end{array}$ & $\begin{array}{l}\text { ICP metals, }{ }^{a} \text { PCB, SVOA, } \\
\text { and TPH }\end{array}$ \\
\hline $\begin{array}{l}\text { Duplicate of J03WJ2 } \\
\text { (western end of trench) }\end{array}$ & Soil & J03WJ3 & $\begin{array}{l}\text { N } 143690 m \\
\text { E } 565663 \mathrm{~m}\end{array}$ & $\begin{array}{c}\text { Base of trench } \\
\text { (approximately } \\
0.5 \mathrm{~m}[1.6 \mathrm{ft}] \mathrm{bgs} \text { ) }\end{array}$ & $\begin{array}{l}\text { ICP metals, }{ }^{a} \text { PCB, SVOA, } \\
\text { and TPH }\end{array}$ \\
\hline
\end{tabular}


Table 2. Verification Sample Summary Table. (2 Pages)

\begin{tabular}{|l|c|c|c|c|l|}
\hline \multicolumn{1}{|c|}{ Sample Location } & $\begin{array}{c}\text { Sample } \\
\text { Media }\end{array}$ & $\begin{array}{c}\text { HEIS } \\
\text { Number }\end{array}$ & $\begin{array}{c}\text { Sample } \\
\text { Coordinates }\end{array}$ & Depth & Sample Analyses \\
\hline Equipment blank & $\begin{array}{c}\text { Silica } \\
\text { sand }\end{array}$ & J03WJ4 & N/A & N/A & ICP metals, ${ }^{\text {a }}$ SVOA \\
\hline
\end{tabular}

Source: Logbook EFL-1173-5 (BHI 2005b).

${ }^{\text {a }}$ The expanded list of ICP metals was performed to include antimony, arsenic, barium, beryllium, boron, cadmium, chromium (total), cobalt, copper, lead, manganese, molybdenum, nickel, silver, selenium, vanadium, and zinc in the analytical results package.

bgs $=$ below ground surface

HEIS = Hanford Environmental Information System

ICP = inductively coupled plasma

$\mathrm{N} / \mathrm{A}=$ not applicable

$\mathrm{PCB}=$ polychlorinated biphenyl

SVOA $=$ semivolatile organic analysis

$\mathrm{TPH}=$ total petroleum hydrocarbon

\section{Verification Sampling Results}

Verification samples were analyzed using U.S. Environmental Protection Agency-approved analytical methods. Comparisons of the maximum detected result for each analyte and the site RAGs are summarized in Table 3 . Contaminants that were not detected by laboratory analysis are excluded from Table 3. The laboratory-reported data results for all constituents are stored in the environmental restoration project-specific database prior to archiving in the Hanford Environmental Information System and are presented in Appendix C.

Table 3. Comparison of Maximum Values to Action Levels at the 600-233 Site. (2 Pages)

\begin{tabular}{|c|c|c|c|c|c|c|}
\hline \multirow[b]{2}{*}{$\mathrm{COC} / \mathrm{COPC}$} & \multirow[b]{2}{*}{$\begin{array}{c}\text { Maximum } \\
\text { Result } \\
(\mathbf{m g} / \mathbf{k g})\end{array}$} & \multicolumn{3}{|c|}{ Remedial Action Goals (mg/kg) } & \multirow[b]{2}{*}{$\begin{array}{l}\text { Does the } \\
\text { Maximum } \\
\text { Result } \\
\text { Exceed } \\
\text { RAGs? }\end{array}$} & \multirow[b]{2}{*}{$\begin{array}{l}\text { Does the } \\
\text { Maximum } \\
\text { Result Pass } \\
\text { RESRAD } \\
\text { Modeling? }\end{array}$} \\
\hline & & $\begin{array}{c}\text { Direct } \\
\text { Exposure }\end{array}$ & $\begin{array}{c}\text { Soil } \\
\text { Concentration } \\
\text { for } \\
\text { Groundwater }^{\text {Protection }^{\mathbf{a}}} \\
\text { Prote }^{-}\end{array}$ & $\begin{array}{c}\text { Soil } \\
\text { Concentration } \\
\text { for River } \\
\text { Protection }^{\mathrm{b}}\end{array}$ & & \\
\hline Barium & $51.2(<\mathrm{BG})$ & $16,000^{\mathrm{c}}$ & $132^{\mathrm{d}}$ & 400 & No & -- \\
\hline Beryllium & $0.41(<\mathrm{BG})$ & $10.4^{\mathrm{e}}$ & $1.51^{\mathrm{d}}$ & $1.51^{\mathrm{d}}$ & No & -- \\
\hline Boron $^{f}$ & 1.5 & $16,000^{\mathrm{c}}$ & 320 & $-\mathrm{g}^{\mathrm{g}}$ & No & -- \\
\hline Cadmium $^{\text {h }}$ & $0.28(<\mathrm{BG})$ & $13.9^{\mathrm{e}}$ & $0.81^{\mathrm{d}}$ & $0.81^{\mathrm{d}}$ & No & - \\
\hline Chromium (total) & $7.9(<\mathrm{BG})$ & 80,000 & $18.5^{\mathrm{d}}$ & $18.5^{\mathrm{d}}$ & No & -- \\
\hline Cobalt & $6.3(<\mathrm{BG})$ & $1,600^{\mathrm{c}}$ & 32 & $--^{\mathrm{g}}$ & No & -- \\
\hline Copper & $11.5(<\mathrm{BG})$ & $2,960^{\mathrm{c}}$ & 59.2 & $22.0^{\mathrm{d}}$ & No & -- \\
\hline Lead & $4.9(<\mathrm{BG})$ & $353^{\mathrm{i}}$ & $10.2^{\mathrm{d}}$ & $10.2^{\mathrm{d}}$ & No & - \\
\hline Manganese & $270(<\mathrm{BG})$ & $11,200^{\mathrm{c}}$ & $512^{d}$ & $--^{g}$ & No & -- \\
\hline Nickel & $8.3(<\mathrm{BG})$ & $1,600^{\mathrm{c}}$ & $19.1^{\mathrm{d}}$ & 27.4 & No & -- \\
\hline
\end{tabular}


Table 3. Comparison of Maximum Values to Action Levels at the 600-233 Site. (2 Pages)

\begin{tabular}{|c|c|c|c|c|c|c|}
\hline \multirow[b]{2}{*}{$\mathrm{COC} / \mathrm{COPC}$} & \multirow[b]{2}{*}{$\begin{array}{c}\text { Maximum } \\
\text { Result } \\
(\mathrm{mg} / \mathrm{kg})\end{array}$} & \multicolumn{3}{|c|}{ Remedial Action Goals (mg/kg) } & \multirow[b]{2}{*}{$\begin{array}{l}\text { Does the } \\
\text { Maximum } \\
\text { Result } \\
\text { Exceed } \\
\text { RAGs? }\end{array}$} & \multirow[b]{2}{*}{$\begin{array}{l}\text { Does the } \\
\text { Maximum } \\
\text { Result Pass } \\
\text { RESRAD } \\
\text { Modeling? }\end{array}$} \\
\hline & & $\begin{array}{c}\text { Direct } \\
\text { Exposure }\end{array}$ & \begin{tabular}{|c|} 
Soil \\
Concentration \\
for \\
Groundwater \\
Protection $^{\mathrm{a}}$
\end{tabular} & $\begin{array}{c}\text { Soil } \\
\text { Concentration } \\
\text { for River } \\
\text { Protection }^{b}\end{array}$ & & \\
\hline Selenium $^{\mathrm{h}}$ & 3.0 & $400^{\mathrm{c}}$ & 5 & 1 & Yes & Yes $^{j}$ \\
\hline Vanadium & $37.0(<\mathrm{BG})$ & $560^{\mathrm{c}}$ & $85.1^{\mathrm{d}}$ & $--^{g}$ & No & -- \\
\hline Zinc & $33.8(<\mathrm{BG})$ & $24,000^{\mathrm{c}}$ & 480 & $67.8^{\mathrm{d}}$ & No & -- \\
\hline Anthracene & 0.047 & $24,000^{\mathrm{c}}$ & 240 & 1,920 & No & -- \\
\hline Benzo(a)anthracene & 0.29 & $1.37^{\mathrm{k}}$ & $0.33^{1}$ & $0.33^{1}$ & No & -- \\
\hline Benzo(a)pyrene & 0.18 & $0.33^{1}$ & $0.33^{1}$ & $0.33^{1}$ & No & -- \\
\hline Benzo(b)fluoranthene & 0.22 & $1.37^{\mathrm{k}}$ & $0.33^{1}$ & $0.33^{1}$ & No & -- \\
\hline Benzo(k)fluoranthene & 0.18 & $13.7^{\mathrm{k}}$ & $0.33^{1}$ & $0.33^{1}$ & No & -- \\
\hline Butylbenzylphthalate & 0.028 & $16,000^{\mathrm{c}}$ & 320 & 250 & No & -- \\
\hline Chrysene & 0.34 & $137^{\mathrm{k}}$ & 1.2 & $0.33^{1}$ & Yes & Yes $^{j}$ \\
\hline Dibenz$[a, h]$ anthracene & 0.061 & $0.33^{1}$ & $0.33^{1}$ & $0.33^{1}$ & No & -- \\
\hline Fluoranthene & 0.69 & $3,200^{c}$ & 64 & 18 & No & -- \\
\hline Indeno(1,2,3-cd)pyrene & 0.11 & $1.37^{\mathrm{k}}$ & $0.33^{1}$ & $0.33^{1}$ & No & - \\
\hline Phenanthrene ${ }^{\mathrm{m}}$ & 0.34 & $24,000^{c}$ & 240 & 1,920 & No & -- \\
\hline Pyrene & 0.51 & $2,400^{c}$ & 48 & 192 & No & -- \\
\hline
\end{tabular}

${ }^{\text {a }}$ Calculated as $100 \mathrm{X}$ MCL unless otherwise noted.

${ }^{\mathrm{b}}$ Calculated as $100 \mathrm{X}$ MCL X 2 (groundwater to river DAF).

${ }^{c}$ Noncarcinogenic cleanup level calculated from WAC 173-340-740(3), Method B, 1996.

${ }^{\mathrm{d}}$ Where cleanup levels are less than background, cleanup levels default to background (WAC 173-340-700[4][d], 1996).

${ }^{\circ}$ Carcinogenic cleanup level calculated based on the inhalation exposure pathway (WAC 173-340-750[3], 1996).

${ }^{\mathrm{f}}$ No Hanford Site-specific or Washington State background value available.

${ }^{g}$ No cleanup level is available from the Ecology Cleanup Levels and Risk Calculations tables, and no toxicity values are available to calculate cleanup levels.

${ }^{\mathrm{h}}$ Hanford Site-specific background is not available; not evaluated during background study. Value used is from Natural Background Soil Metals Concentrations in Washington State (Ecology 1994).

i A WAC 173-340-740(3) (1996) value for lead is not available. This value is based on the Guidance Manual for the Integrated Exposure Update Biokinetic Model for Lead in Children (EPA 1994).

${ }^{\mathrm{j}}$ Based on the 100 Area Analogous Sites RESRAD Calculations (BHI 2005a), with a groundwater table elevation of $120 \mathrm{~m}$ $(394 \mathrm{ft})$ and a clean zone extending from groundwater to an elevation of $146 \mathrm{~m}(479 \mathrm{ft})$.

${ }^{\mathrm{k}}$ Carcinogenic cleanup level calculated per WAC 173-340-740(3), Method B, 1996.

${ }^{1}$ Where cleanup levels are less than RDL, cleanup levels default to the RDL (WAC 173-340-707[2], 1996).

$\mathrm{m}$ Toxicity data for phenanthrene are not available. Cleanup levels are based on the surrogate chemical anthracene.

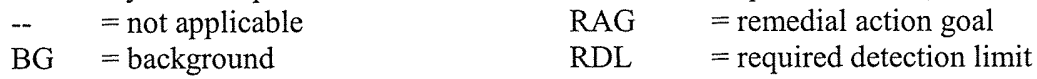

$\mathrm{COC}=$ contaminant of concern $\quad$ RESRAD $=$ RESidual RADioactivity (dose model)

$\mathrm{COPC}=$ contaminant of potential concern $\mathrm{WAC}=$ Washington Administrative Code

$\mathrm{DAF}=$ dilution attenuation factor

$\mathrm{MCL}=$ maximum contaminant level (drinking water standard) 


\section{DATA EVALUATION}

In accordance with the focused sampling approach and WAC 173-340-740(7)(d)(iii), direct comparison of the sample results with the RAGs is an acceptable method to evaluate compliance with cleanup objectives for the 600-233 site. All COCs and COPCs, with the exception of selenium and chrysene, are less than background or applicable RAGs. Residual concentrations of selenium and chrysene are below their respective direct exposure cleanup levels but exceed their respective soil RAGs for protection of the Columbia River. As allowed by WAC 173-340-740(3)(a)(ii)(A), an analogous site contaminant depth distribution model was used to demonstrate that these vadose zone soil concentrations are protective of river water. Results of the 100 Area Analogous Sites RESRAD Calculations (BHI 2005a) indicate that neither of these contaminants will reach groundwater (and therefore the Columbia River) within a 1,000-year time frame. Therefore, the residual concentrations achieve the RAOs for river protection.

Nonradionuclide risk requirements for the 600-233 site include an individual hazard quotient of less than 1.0, a cumulative hazard quotient of less than 1.0, an individual contaminant carcinogenic risk of less than $1 \times 10^{-6}$, and a cumulative carcinogenic risk of less than $1 \times 10^{-5}$. These risk values were not calculated for constituents that were either not detected or detected at concentrations below Hanford Site or Washington State background values. All individual hazard quotients for noncarcinogenic constituents were less than 1.0 (Appendix D). The cumulative hazard quotient for those noncarcinogenic constituents above background or detection levels is $8.0 \times 10^{-3}$. The individual carcinogenic risk values for carcinogenic constituents above background or detection levels are all below $1 \times 10^{-6}$ (Appendix D). The cumulative carcinogenic risk value for these constituents is $2.2 \times 10^{-6}$, which is below $1 \times 10^{-5}$.

When using a statistical sampling approach, a RAG requirement for nonradionuclides is the WAC 173-340-740(7)(e) three-part test. However, this test is not applicable to this focused sampling approach because maximum detected concentration data are used as the compliance basis.

\section{DATA QUALITY ASSESSMENT}

A data quality assessment (DQA) review was performed to compare the verification sampling approach and analytical data with the sampling and data requirements specified by the project objectives. This review involves evaluation of the data to determine if it is of the right type, quality, and quantity to support the intended use (i.e., closeout decisions [EPA 2000]).

Examination of the data in consideration of cleanup objectives and residual risk is presented in the preceding data evaluation section. The DQA review completes the data life cycle (i.e., planning, implementation, and assessment) that was initiated by the data process.

This DQA review was performed in accordance with BHI-EE-01, Environmental Investigations Procedures. Specific data quality objectives for the site are found in the 100 Area Remedial Action Sampling and Analysis Plan (SAP) (DOE-RL 2005a). All samples were collected per agreements with the lead regulatory agency. The data quality requirements in the SAP are used 
for assessing data from statistical sampling and do not specifically apply to the data sets resulting from the focused sampling performed for this site. However, to ensure quality data sets, the SAP data quality requirements as well as the validation procedures for chemical and radiochemical analysis (BHI 2000a, 2000b) are followed where appropriate.

Sample delivery group (SDG) H3321 was generated by verification sampling at the 600-233 site, consisting of three field samples (J03WJ1, J03WJ2, and J03WJ3) and an equipment blank (J03WJ4). The samples were analyzed as described in Table 2. This SDG was subjected to third-party validation, and no major deficiencies were found. No minor deficiencies were found in the analyses of polychlorinated biphenyls, ICP metals, or total petroleum hydrocarbons. All of these data are useable for decision-making purposes.

In the SVOC analyses, the common laboratory contaminant bis(2ethylhexyl)phthalate was detected in the method blank. Third-party validation requalified all of the sample results as undetected at the required detection limit (RDL). Method blank contamination was also observed for di-n-butyl phthalate, benzo(b)fluoranthene, indeno(1,2,3-cd)pyrene, and benzo(g,h,i)perylene. Third-party validation requalified these analytes in samples J03WJ2 and J03WJ3 as undetected and raised the reported values to the RDLs. Finally, the SVOC analyte benzo(k)fluoranthene was requalified as undetected at the RDL for samples J03WJ1, J03WJ2, and J03WJ3 due to method blank contamination. All of the data were found to be useable for decision-making purposes.

Sample J03WJ3 was a field duplicate of sample J03WJ2. The only significant differences observed between samples J03WJ2 and J03WJ3 were in the SVOC analysis, where detected analytes in sample $\mathrm{J} 03 \mathrm{WJ} 2$ are consistently greater than the corresponding analytes in sample J03WJ3. This type of result in environmental samples is generally attributed to naturally occurring heterogeneity in the sample matrix and not an indication of any problem with the sampling technique or the analytical methodology.

Limited, random, or sample matrix-specific influenced batch quality control issues such as these are a potential for any analysis. The number and types seen in these data sets were within expectations for the matrix types and analyses performed.

The DQA review for the 600-233 site found the results to be accurate within the standard errors associated with the methods, including sampling and sample handling. The DQA review for the 600-233 site concludes that the data are of the right type, quality, and quantity to support the intended use. Detection limits, precision, accuracy, and sampling data group completeness were assessed to determine if any analytical results should be rejected as a result of quality assurance and quality control deficiencies. All analytical data were found to be acceptable for decisionmaking purposes.

\section{SUMMARY FOR INTERIM CLOSURE}

The 600-233 waste site has been evaluated and remediated in accordance with the Remaining Sites ROD (EPA 1999) and the RDR/RAWP (DOE-RL 2005b). The verification sampling 
results were used to demonstrate the site meets the cleanup objectives for direct exposure, groundwater protection, and river protection. In accordance with this evaluation, the sampling results support a reclassification of the 600-233 site to interim closed out in accordance with the Hanford Federal Facility Agreement and Consent Order (Ecology et al. 1989) and Waste Site Reclassification Guideline TPA-MP-14 (DOE-RL 1998). This site does not have a deep zone; therefore, no deep zone institutional controls are required.

\section{REFERENCES}

40 CFR 141, "National Primary Drinking Water Regulations," Code of Federal Regulations, as amended.

Bergstrom, K. A. and T. H. Mitchell, 2003, Results of Geophysical Investigations at Remaining Sites 100 B/C Area: 118-B-9 Tritium Lab and Vault, 100-B-6, 100-B-11, 100-B-14, and 600-232 Hanford Area Townsite: 600-3, CCN 109948, dated December 2, 2003, Bechtel Hanford, Inc., Richland, Washington.

BHI, 2001, Calculation of Total Uranium Activity Corresponding to a Maximum Contaminant Level for Total Uranium of 30 Micrograms per Liter in Groundwater, 0100X-CA-V0038, Rev. 0, Bechtel Hanford, Inc., Richland, Washington.

BHI, 2000a, Data Validation Procedure for Radiochemical Analysis, BHI-01433, Rev. 0, Bechtel Hanford, Inc., Richland, Washington.

BHI, 2000b, Data Validation Procedure for Chemical Analysis, BHI-01435, Rev. 0, Bechtel Hanford, Inc., Richland, Washington.

BHI, 2003, 100B/C Burial Grounds/Remaining Sites Sampling and Field Activities, Logbook EFL-1173, Bechtel Hanford, Inc., Richland, Washington.

BHI, 2005a, 100 Area Analogous Sites RESRAD Calculations, 0100X-CA-V0050, Rev. 0, Bechtel Hanford, Inc., Richland, Washington.

BHI, 2005b, Remaining Site Field Sampling, Logbook EL-1173-5, Bechtel Hanford, Inc., Richland, Washington.

BHI, 2005c, Work Instruction for Verification Sampling of the 600-233 Waste Site, Vertical Pipe Near 100-B Electrical Laydown Area, 0100B-WI-G0001, Bechtel Hanford, Inc., Richland, Washington.

BHI-EE-01, Environmental Investigations Procedures, Bechtel Hanford, Inc., Richland, Washington

DOE Order 5400.5, Radiation Protection of the Public and the Environment, as amended, U.S. Department of Energy, Washington, D.C. 
DOE-RL, 1998, Tri-Party Agreement Handbook Management Procedures, RL-TPA-90-0001, Guideline Number TPA-MP-14, "Maintenance of the Waste Information Data System (WIDS)," U.S. Department of Energy, Richland Operations Office, Richland, Washington.

DOE-RL, 2005a, 100 Area Remedial Action Sampling and Analysis Plan, DOE/RL-96-22, Rev. 4, U.S. Department of Energy, Richland Operations Office, Richland, Washington.

DOE-RL, 2005b, Remedial Design Report/Remedial Action Work Plan for the 100 Area, DOE/RL-96-17, Rev. 5, U.S. Department of Energy, Richland Operations Office, Richland, Washington.

DOE-RL and EPA, 2004, Remaining Sites Verification Package for the 600-232, 100B Electrical Laydown Area (Attachment to Waste Site Reclassification Form 2004-066), Rev. 0, U.S. Department of Energy, Richland Operations Office, and U.S. Environmental Protection Agency, Region 10, Seattle, Washington.

Ecology, 1994, Natural Background Soil Metals Concentrations in Washington State, Publication No. 94-115, Washington State Department of Ecology, Olympia, Washington.

Ecology, EPA, and DOE, 1989, Hanford Federal Facility Agreement and Consent Order, 2 vols., as amended, Washington State Department of Ecology, U.S. Environmental Protection Agency, and U.S. Department of Energy, Olympia, Washington.

EPA, 1994, Guidance Manual for the Integrated Exposure Uptake Biokinetic Model for Lead in Children, EPA/540/R-93/081, Publication No. 9285.7-15-1, U.S. Environmental Protection Agency, Washington, D.C.

EPA, 1999, Interim Action Record of Decision for the 100-BC-1, 100-BC-2, 100-DR-1, 100-DR-2, 100-FR-1, 100-FR-2, 100-HR-1, 100-HR-2, 100-KR-1, 100-KR-2, 100-IU-2, 100-IU-6, and 200-CW-3 Operable Units, Hanford Site, Benton County, Washington, U.S. Environmental Protection Agency, Region 10, Seattle, Washington.

EPA, 2000, Guidance for Data Quality Assessment, EPA QA/G-9, EPA/600/R-96/084, U.S. Environmental Protection Agency, Washington, D.C.

WAC 173-340, 1996, "Model Toxics Control Act -- Cleanup," Washington Administrative Code. 


\section{APPENDIX A}

\section{HISTORICAL PHOTOGRAPHY \\ (1 Page)}


Photograph 1. Photograph of the Above-Grade Vertical Pipe at the 600-233 Waste Site.

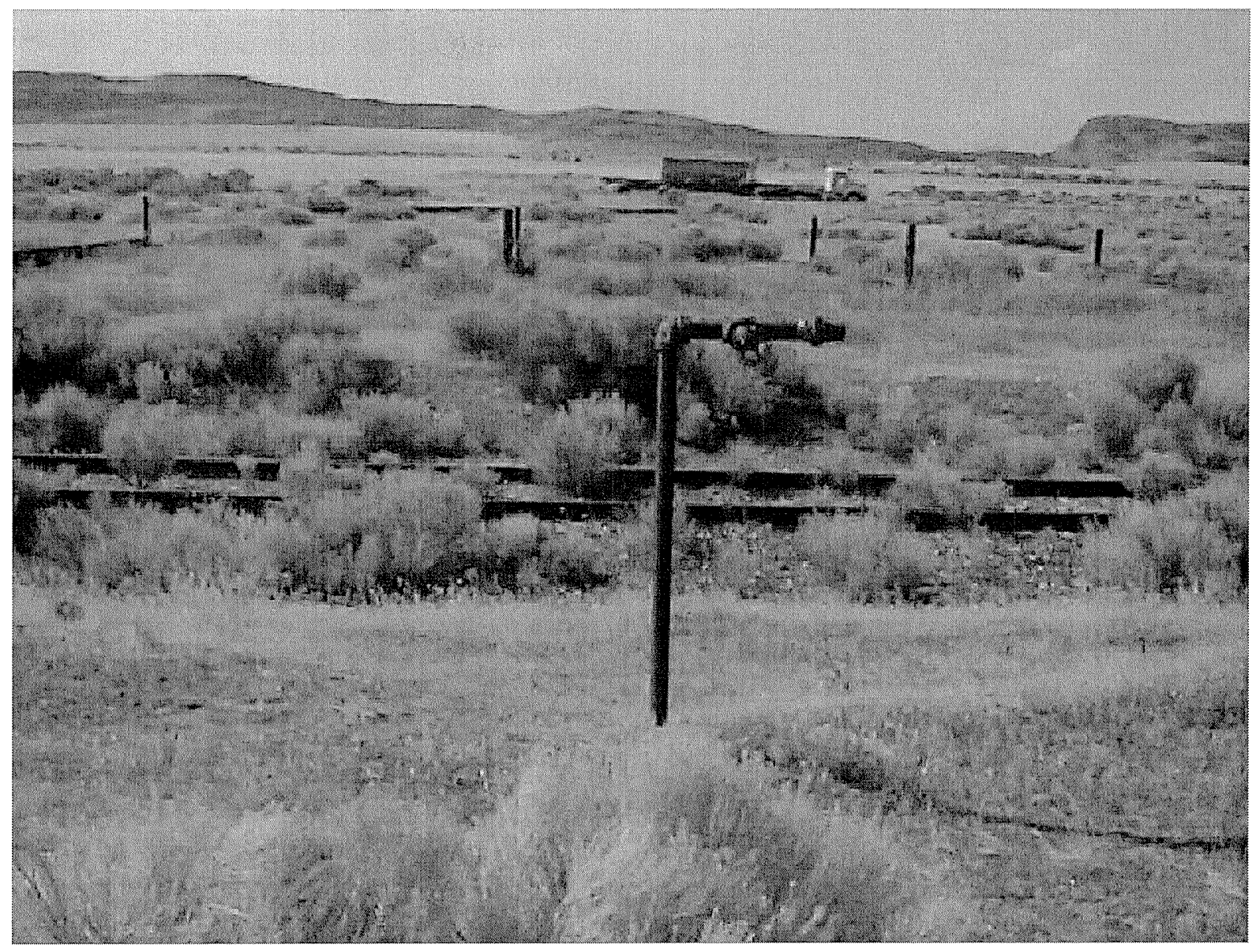




\section{APPENDIX B}

\section{CONFIRMATORY AND WASTE CHARACTERIZATION SAMPLING RESULTS \\ (7 Pages)}


Table B-1. 600-233 Confirmatory Sampling Results.

\begin{tabular}{|c|c|c|c|c|c|c|c|c|c|c|c|c|c|c|c|c|c|}
\hline Sample Location & $\begin{array}{c}\text { HEIS } \\
\text { Number }\end{array}$ & $\begin{array}{c}\text { Sample } \\
\text { Date }\end{array}$ & \multicolumn{3}{|c|}{ Arsenic } & \multicolumn{2}{|c|}{ Barium } & \multicolumn{2}{|c|}{ Cadmium } & \multicolumn{3}{|c|}{ Chromium } & \multicolumn{2}{|c|}{ Lead } & \multicolumn{3}{|c|}{ Mercury } \\
\hline Vertical pipe (scale) & J01FT9 & $05 / 20 / 04$ & 22.7 & & 1.9 & 8.1 & 0.11 & 2.3 & 0.22 & 55.7 & $\mathrm{C}$ & 0.28 & 7730 & 1.1 & 0.06 & & 0.02 \\
\hline
\end{tabular}

\begin{tabular}{|c|c|c|c|c|c|c|c|c|}
\hline \multirow{2}{*}{ Sample Location } & HEIS & Sample & \multicolumn{3}{|c|}{ Selenium } & \multicolumn{3}{c|}{ Silver } \\
\cline { 4 - 8 } & Number & Date & $\mathbf{m g} / \mathbf{k g}$ & $\mathbf{Q}$ & $\mathbf{P Q L}$ & $\mathbf{m g} / \mathbf{k g}$ & $\mathbf{Q}$ & PQL \\
\hline Vertical pipe (scale) & J01FT9 & $05 / 20 / 04$ & 1.9 & U & 1.9 & 0.34 & U & 0.34 \\
\hline
\end{tabular}

\begin{tabular}{|l|c|c|c|c|c|}
\hline \multirow{2}{*}{ Constituent } & \multirow{2}{*}{$\begin{array}{c}\text { HEIS } \\
\text { Number }\end{array}$} & \multirow{2}{*}{$\begin{array}{c}\text { Sample } \\
\text { Date }\end{array}$} & \multicolumn{3}{|c|}{ PCBs } \\
\cline { 5 - 7 } & Nog/kg & Q & PQL \\
\hline Aroclor-1016 & J01FT9 & $05 / 20 / 04$ & 27 & U & 27 \\
\hline Aroclor-1221 & J01FT9 & $05 / 20 / 04$ & 27 & U & 27 \\
\hline Aroclor-1232 & J01FT9 & $05 / 20 / 04$ & 27 & U & 27 \\
\hline Aroclor-1242 & J01FT9 & $05 / 20 / 04$ & 27 & U & 27 \\
\hline Aroclor-1248 & J01FT9 & $05 / 20 / 04$ & 27 & U & 27 \\
\hline Aroclor-1254 & J01FT9 & $05 / 20 / 04$ & 27 & U & 27 \\
\hline Aroclor-1260 & J01FT9 & $05 / 20 / 04$ & 120 & U & 120 \\
\hline
\end{tabular}

Acronyms and notes apply to all of the tables in this appendix.

Note: Data qualified with B, C, D, and/or J are considered acceptable values for decision-making purposes.

$\mathrm{B}=$ blank contamination (organic constituents)

$\mathrm{BHC}=$ hexachlorocyclohexane

$\mathrm{C}=$ blank contamination (inorganic constituents)

$\mathrm{D}=$ diluted

DEG $F=$ degree Fahrenheit

GEA = gamma energy analysis

HEIS = Hanford Environmental Information System

$\mathrm{J}=$ estimate

$\mathrm{MDA}=$ minimum detectable activity

$\mathrm{PCB}=$ polychlorinated biphenyl

$\mathrm{PQL}=$ practical quantitation limit

$\mathrm{Q}=$ qualifier

SVOA = semivolatile organic analyte

$\mathrm{TPH}=$ total petroleum hydrocarbon

TPH-D $=$ total petroleum hydrocarbon-diesel

$\mathrm{U}=$ undetected 
Table B-2. 600-233 Waste Characterization and In-Process Sampling Results. (6 Pages)

\begin{tabular}{|c|c|c|c|c|c|c|c|c|c|c|c|c|c|c|c|c|c|c|c|c|}
\hline \multirow{2}{*}{ Sample Location } & \multirow{2}{*}{$\begin{array}{c}\text { HEIS } \\
\text { Number }\end{array}$} & \multirow{2}{*}{$\begin{array}{c}\text { Sample } \\
\text { Date }\end{array}$} & \multicolumn{3}{|c|}{ Americium-241 GEA } & \multicolumn{3}{|c|}{ Cesium-137 } & \multicolumn{3}{|c|}{ Cobalt-60 } & \multicolumn{3}{|c|}{ Europium-152 } & \multicolumn{3}{|c|}{ Europium-154 } & \multicolumn{3}{|c|}{ Europium-155 } \\
\hline & & & $\mathrm{pCi} / \mathrm{g}$ & Q & MDA & $\mathrm{pCi} / \mathrm{g}$ & Q & MDA & $\mathrm{Ci} / \mathrm{g}$ & Q & MDA & $\mathrm{pCi} / \mathrm{g}$ & $Q$ & MDA & $\mathrm{pCi} / \mathrm{g}$ & Q & MDA & $\mathrm{pCi} / \mathrm{g}$ & Q & MDA \\
\hline grain scal & J01ML5 & $08 / 23 / 04$ & 0.23 & $\mathrm{U}$ & 0.23 & 0.064 & $\mathrm{U}$ & 0.064 & 0.072 & $\mathrm{U}$ & 0.072 & 0.17 & & 0.17 & 0.2 & $\mathrm{u}$ & 0.2 & 0.14 & U & 0.14 \\
\hline
\end{tabular}

\begin{tabular}{|c|c|c|c|c|c|c|c|c|c|c|c|c|c|c|c|c|c|c|c|c|}
\hline Sample Location & $\begin{array}{c}\text { HEIS } \\
\text { Number }\end{array}$ & $\begin{array}{c}\text { Sample } \\
\text { Date }\end{array}$ & \multicolumn{3}{|c|}{ Gross alpha } & \multicolumn{3}{|c|}{ Gross beta } & \multicolumn{3}{|c|}{ Potassium-40 } & \multicolumn{3}{|c|}{ Radium-226 } & \multicolumn{3}{|c|}{ Radium-228 } & \multicolumn{3}{|c|}{ Silver-108 m } \\
\hline $\begin{array}{l}2.5 \text {-in. pipe, dark gray } \\
\text { fine grain scale }\end{array}$ & J01ML5 & $08 / 23 / 04$ & 0.768 & $\mathrm{U}$ & 6 & 2.21 & $U$ & 7.2 & 1.62 & & 0.75 & 0.12 & $\mathrm{U}$ & 0.12 & 0.29 & $\mathrm{U}$ & 0.29 & 0.049 & $U$ & 0.049 \\
\hline
\end{tabular}

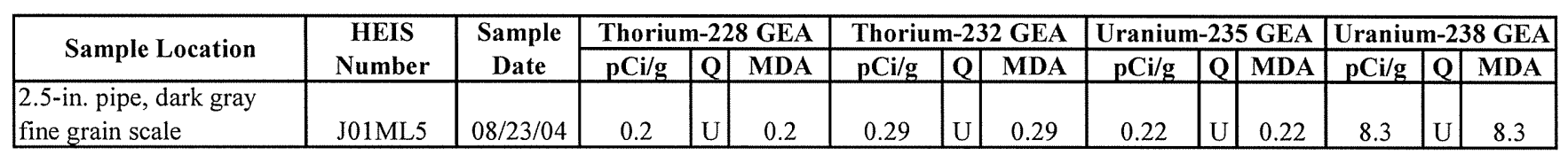


Table B-2. 600-233 Waste Characterization and In-Process Sampling Results. (6 Pages)

\begin{tabular}{|c|c|c|c|c|c|c|c|c|c|c|c|c|c|c|c|c|c|c|c|c|}
\hline \multirow{2}{*}{ Sample Location } & \multirow{2}{*}{$\begin{array}{c}\text { HEIS } \\
\text { Number }\end{array}$} & \multirow{2}{*}{$\begin{array}{l}\text { Sample } \\
\text { Date }\end{array}$} & \multicolumn{3}{|c|}{ Arsenic } & \multicolumn{3}{|c|}{ Barium } & \multicolumn{3}{|c|}{ Cadmium } & \multicolumn{3}{|c|}{ Chromium } & \multicolumn{3}{|c|}{ Cyanide } & \multicolumn{3}{|c|}{ Lead } \\
\hline & & & $\mathrm{mg} / \mathrm{kg}$ & Q & PQL & $\mathrm{mg} / \mathrm{kg}$ & Q & PQL & $\mathrm{mg} / \mathrm{kg}$ & Q & PQL & $\mathrm{mg} / \mathrm{kg}$ & Q & PQL & $\mathrm{mg} / \mathrm{kg}$ & $\mathbf{Q}$ & PQL & $\mathrm{mg} / \mathrm{kg}$ & Q & PQL \\
\hline $\begin{array}{l}\text { Soil impacted by leak in } \\
2.5 \text {-in. pipe }\end{array}$ & J01PT9* & $08 / 23 / 04$ & & & & & & & & & & & & & 0.47 & $\mathrm{U}$ & 0.47 & & & \\
\hline $\begin{array}{l}\text { Suspect diesel (discovery } \\
\text { pipelines) }\end{array}$ & J02635 & $12 / 27 / 04$ & 1.0 & & 0.22 & 0.08 & C & 0.03 & 0.03 & $\mathrm{U}$ & 0.03 & 0.15 & & 0.07 & & & & 1.5 & & 0.19 \\
\hline
\end{tabular}

\begin{tabular}{|c|c|c|c|c|c|c|c|c|c|c|c|c|c|c|c|c|c|c|c|c|}
\hline \multirow{2}{*}{ Sample Location } & \multirow{2}{*}{$\begin{array}{c}\text { HEIS } \\
\text { Number }\end{array}$} & \multirow{2}{*}{$\begin{array}{c}\text { Sample } \\
\text { Date } \\
\end{array}$} & \multicolumn{3}{|c|}{ Mercury } & \multicolumn{3}{|c|}{ Selenium } & \multicolumn{3}{|c|}{ Silver } & \multicolumn{3}{|c|}{ Sulfide } & \multicolumn{3}{|c|}{ TPH } & \multicolumn{3}{|c|}{ TPH-D } \\
\hline & & & $\mathrm{mg} / \mathrm{kg}$ & $Q$ & PQL & $\mathrm{mg} / \mathrm{kg}$ & $\mathbf{Q}$ & PQL & $\mathrm{mg} / \mathrm{kg}$ & $Q$ & PQL & $\mathrm{mg} / \mathrm{kg}$ & $Q$ & PQL & $\mathrm{mg} / \mathrm{kg}$ & $\mathbf{Q}$ & PQL & $\mathrm{mg} / \mathrm{kg}$ & $\mathbf{Q}$ & PQL \\
\hline $\begin{array}{l}\text { Suspect waste oil in glass } \\
\text { jug }\end{array}$ & J01J83** & $05 / 20 / 04$ & & & & & & & & & & & & & 329000 & & 120000 & & & \\
\hline $\begin{array}{l}\text { Soil impacted by leak in } \\
2.5 \text {-in. pipe }\end{array}$ & J01PT9* & $08 / 23 / 04$ & & & & & & & & & & 43.9 & $\mathrm{U}$ & 43.9 & & & & & & \\
\hline $\begin{array}{l}\text { Suspect diesel (discovery } \\
\text { pipelines) }\end{array}$ & $\mathrm{J} 01 \mathrm{YT}^{* * * *}$ & $10 / 22 / 04$ & & & & & & & & & & & & & & & & 1800000 & $D$ & 120000 \\
\hline $\begin{array}{l}\text { Soil, northern end of short } \\
\text { discovery pipeline }\end{array}$ & $\mathrm{J} 02553 * *$ & $12 / 06 / 04$ & & & & & & & & & & & & & 46.4 & & 34.9 & & & \\
\hline $\begin{array}{l}\text { Soil, southern end of short } \\
\text { discovery pipeline }\end{array}$ & $\mathrm{J} 02554^{* *}$ & $12 / 06 / 04$ & & & & & & & & & & & & & 35.4 & $\mathrm{U}$ & 35.4 & & & \\
\hline $\begin{array}{l}\text { Suspect diesel (discovery } \\
\text { pipelines) }\end{array}$ & $\mathrm{J} 02635$ & $12 / 27 / 04$ & 0.16 & $\mathrm{U}$ & 0.16 & 0.87 & & 0.31 & 0.08 & $\mathrm{U}$ & 0.08 & & & & & & & & & \\
\hline
\end{tabular}

* Only analytes were cyanide and sulfide.

** Only analyte was TPH.

*** Only analyte was TPH-D.

\begin{tabular}{|l|c|c|c|}
\hline \multicolumn{1}{|c|}{ Sample Location } & $\begin{array}{c}\text { HEIS } \\
\text { Number }\end{array}$ & $\begin{array}{c}\text { Sample } \\
\text { Date }\end{array}$ & Ignitability \\
\cline { 4 - 5 } $\begin{array}{l}\text { Suspect waste oil in glass } \\
\text { jug }\end{array}$ & J01J83 & $05 / 20 / 04$ & DEG F \\
\hline $\begin{array}{l}\text { Suspect diesel (discovery } \\
\text { pipelines) }\end{array}$ & $\mathrm{J} 02635$ & $12 / 27 / 04$ & 168.0 \\
\hline
\end{tabular}


Table B-2. 600-233 Waste Characterization and In-Process Sampling Results.* (6 Pages)

\begin{tabular}{|c|c|c|c|c|c|c|c|c|c|}
\hline \multirow[t]{2}{*}{ Constituent } & \multicolumn{3}{|c|}{$\begin{array}{c}\text { J01ML5 } \\
\text { Sample Date 08/23/04 } \\
\end{array}$} & \multicolumn{3}{|c|}{$\begin{array}{c}\text { J01PT9 } \\
\text { Sample Date 08/23/04 } \\
\end{array}$} & \multicolumn{3}{|c|}{$\begin{array}{c}\text { J02635 } \\
\text { Sample Date 12/27/04 }\end{array}$} \\
\hline & $\mu \mathrm{g} / \mathrm{kg}$ & $\mathbf{Q}$ & PQL & $\mu \mathrm{g} / \mathrm{kg}$ & $\mathbf{Q}$ & PQL & $\mu \mathrm{g} / \mathrm{kg}$ & $\mathbf{Q}$ & PQL \\
\hline \multicolumn{10}{|c|}{ Herbicides } \\
\hline 2,4,5-Trichlorophenoxyacetic acid & & & & 17 & $\mathrm{U}$ & 17 & & & \\
\hline 2,4-Dichlorophenoxyacetic acid & & & & 33 & $\mathrm{U}$ & 33 & & & \\
\hline 2-(2,4,5-Trichlorophenoxy)propionic acid & & & & 17 & $\mathrm{U}$ & 17 & & & \\
\hline 2-secButyl-4,6-dinitrophenol(DNBP) & & & & 17 & $\mathrm{U}$ & 17 & & & \\
\hline 4-(2,4-Dichlorophenoxy)butanoic acid & & & & 170 & $\mathrm{U}$ & 170 & & & \\
\hline Dalapon & & & & 170 & $\mathrm{U}$ & 170 & & & \\
\hline Dicamba & & & & 67 & $\mathrm{U}$ & 67 & & & \\
\hline Dichloroprop & & & & 170 & $\mathrm{U}$ & 170 & & & \\
\hline \multicolumn{10}{|c|}{ Polychlorinated Biphenyls (PCBs) } \\
\hline Aroclor-1016 & 230 & $\mathrm{U}$ & 230 & & & & 1000 & $\mathrm{U}$ & 1000 \\
\hline Aroclor-1221 & 230 & $\mathrm{U}$ & 230 & & & & 1000 & $U$ & 1000 \\
\hline Aroclor-1232 & 230 & $\mathrm{U}$ & 230 & & & & 1000 & $\mathrm{U}$ & 1000 \\
\hline Aroclor-1242 & 230 & $\mathrm{U}$ & 230 & & & & 1000 & $\mathrm{U}$ & 1000 \\
\hline Aroclor-1248 & 230 & $\mathrm{U}$ & 230 & & & & 1000 & $\mathrm{U}$ & 1000 \\
\hline Aroclor-1254 & 230 & $\mathrm{U}$ & 230 & & & & 1000 & $U$ & 1000 \\
\hline Aroclor-1260 & 230 & $\mathrm{U}$ & 230 & & & & 1000 & $\mathrm{U}$ & 1000 \\
\hline \multicolumn{10}{|c|}{ Pesticides } \\
\hline Aldrin & & & & 1.7 & $\mathrm{U}$ & 1.7 & & & \\
\hline Alpha-BHC & & & & 1.7 & $\mathrm{U}$ & 1.7 & & & \\
\hline alpha-Chlordane & & & & 1.7 & $\mathrm{U}$ & 1.7 & & & \\
\hline beta-1,2,3,4,5,6-Hexachlorocyclohexane & & & & 1.7 & $\mathrm{U}$ & 1.7 & & & \\
\hline Delta-BHC & & & & 1.7 & $\mathrm{U}$ & 1.7 & & & \\
\hline Dichlorodiphenyldichloroethane & & & & 3.3 & $\mathrm{U}$ & 3.3 & & & \\
\hline Dichlorodiphenyldichloroethylene & & & & 3.3 & $\mathrm{U}$ & 3.3 & & & \\
\hline Dichlorodiphenyltrichloroethane & & & & 3.3 & $\mathrm{U}$ & 3.3 & & & \\
\hline Dieldrin & & & & 3.3 & $\mathrm{U}$ & 3.3 & & & \\
\hline Endosulfan I & & & & 1.7 & $\mathrm{U}$ & 1.7 & & & \\
\hline Endosulfan II & & & & 3.3 & $\mathrm{U}$ & 3.3 & & & \\
\hline Endosulfan sulfate & & & & 3.3 & $\mathrm{U}$ & 3.3 & & & \\
\hline Endrin & & & & 3.3 & $\mathrm{U}$ & 3.3 & & & \\
\hline Endrin aldehyde & & & & 3.3 & $\mathrm{U}$ & 3.3 & & & \\
\hline Endrin ketone & & & & 3.3 & $\mathrm{U}$ & 3.3 & & & \\
\hline Gamma-BHC (Lindane) & & & & 1.7 & $\mathrm{U}$ & 1.7 & & & \\
\hline gamma-Chlordane & & & & 1.7 & $\mathrm{U}$ & 1.7 & & & \\
\hline Heptachlor & & & & 1.7 & $\mathrm{U}$ & 1.7 & & & \\
\hline Heptachlor epoxide & & & & 1.2 & $\mathrm{U}$ & 1.2 & & & \\
\hline Methoxychlor & & & & 17 & $\mathrm{U}$ & 17 & & & \\
\hline Toxaphene & & & & 170 & $\mathrm{U}$ & 170 & & & \\
\hline
\end{tabular}

* TPH data is located with the inorganic data. 
Table B-2. 600-233 Waste Characterization and In-Process Sampling Results. (6 Pages)

\begin{tabular}{|c|c|c|c|c|c|c|c|}
\hline \multirow[t]{2}{*}{ Constituent } & \multicolumn{3}{|c|}{$\begin{array}{c}\text { J02635 } \\
\text { Sample Date 12/27/04 } \\
\end{array}$} & \multirow[t]{2}{*}{ Constituent } & \multicolumn{3}{|c|}{$\begin{array}{c}\text { J02635 } \\
\text { Sample Date 12/27/04 }\end{array}$} \\
\hline & $\mu \mathrm{g} / \mathrm{kg}$ & $\mathbf{Q}$ & PQL & & $\mu \mathrm{g} / \mathrm{kg}$ & $\mathbf{Q}$ & PQL \\
\hline \multicolumn{8}{|c|}{ Semivolatile Organic Analytes (SVOAs) } \\
\hline 1,2,4-Trichlorobenzene & 200000 & $\mathrm{U}$ & 200000 & Benzo(b)fluoranthene & 200000 & $\mathrm{U}$ & 200000 \\
\hline 1,2-Dichlorobenzene & 200000 & $\mathrm{U}$ & 200000 & Benzo(ghi)perylene & 200000 & $\mathrm{U}$ & 200000 \\
\hline 1,3-Dichlorobenzene & 200000 & $\mathrm{U}$ & 200000 & Benzo(k)fluoranthene & 200000 & $\mathrm{U}$ & 200000 \\
\hline 1,4-Dichlorobenzene & 200000 & $\mathrm{U}$ & 200000 & Bis(2chlorolmethylethyl)ether & 200000 & $\mathrm{U}$ & 200000 \\
\hline 2,4,5-Trichlorophenol & 500000 & $\mathrm{U}$ & 500000 & Bis(2-Chloroethoxy)methane & 200000 & $\mathrm{U}$ & 200000 \\
\hline 2,4,6-Trichlorophenol & 200000 & $\mathrm{U}$ & 200000 & Bis(2-chloroethyl) ether & 200000 & $\mathrm{U}$ & 200000 \\
\hline 2,4-Dichlorophenol & 200000 & $\mathrm{U}$ & 200000 & Bis(2-ethylhexyl) phthalate & 200000 & $\mathrm{U}$ & 200000 \\
\hline 2,4-Dimethylphenol & 200000 & $\mathrm{U}$ & 200000 & Butylbenzylphthalate & 200000 & $\mathrm{U}$ & 200000 \\
\hline 2,4-Dinitrophenol & 500000 & $\mathrm{U}$ & 500000 & Carbazole & 200000 & $\mathrm{U}$ & 200000 \\
\hline 2,4-Dinitrotoluene & 200000 & $\mathrm{U}$ & 200000 & Chrysene & 200000 & $\bar{U}$ & 200000 \\
\hline 2,6-Dinitrotoluene & 200000 & $\mathrm{U}$ & 200000 & Di-n-butylphthalate & 200000 & $\mathrm{U}$ & 200000 \\
\hline 2-Chloronaphthalene & 200000 & $\mathrm{U}$ & 200000 & \begin{tabular}{|l} 
Di-n-octylphthalate \\
\end{tabular} & 200000 & $\mathrm{U}$ & 200000 \\
\hline 2-Chlorophenol & 200000 & $\mathrm{U}$ & 200000 & Dibenz $[\mathrm{a}, \mathrm{h}]$ anthracene & 200000 & $\mathrm{U}$ & 200000 \\
\hline 2-Methylnaphthalene & 2700000 & $\mathrm{D}$ & 2000000 & Dibenzofuran & 200000 & $\mathrm{U}$ & 200000 \\
\hline 2-Methylphenol (cresol, o-) & 200000 & $\mathrm{U}$ & 200000 & Diethylphthalate & 200000 & $\mathrm{U}$ & 200000 \\
\hline 2-Nitroaniline & 500000 & $\mathrm{U}$ & 500000 & Dimethyl phthalate & 200000 & $\mathrm{U}$ & 200000 \\
\hline 2-Nitrophenol & 200000 & $\mathrm{U}$ & 200000 & Fluoranthene & 200000 & $\mathrm{U}$ & 200000 \\
\hline $3+4$ Methylphenol (cresol, $\mathrm{m}+\mathrm{p}$ ) & 200000 & $\mathrm{U}$ & 200000 & Fluorene & 230000 & & 200000 \\
\hline 3,3'-Dichlorobenzidine & 200000 & $\mathrm{U}$ & 200000 & Hexachlorobenzene & 200000 & $\bar{U}$ & 200000 \\
\hline 3-Nitroaniline & 500000 & $\mathrm{U}$ & 500000 & Hexachlorobutadiene & 200000 & $\mathrm{U}$ & 200000 \\
\hline 4,6-Dinitro-2-methylphenol & 500000 & $\mathrm{U}$ & 500000 & Hexachlorocyclopentadiene & 200000 & $\mathrm{U}$ & 200000 \\
\hline 4-Bromophenylphenyl ether & 200000 & $\mathrm{U}$ & 200000 & Hexachloroethane & 200000 & $\mathrm{U}$ & 200000 \\
\hline 4-Chloro-3-methylphenol & 200000 & $\mathrm{U}$ & 200000 & Indeno(1,2,3-cd)pyrene & 200000 & $\mathrm{U}$ & 200000 \\
\hline 4-Chloroaniline & 200000 & $\mathrm{U}$ & 200000 & Isophorone & 200000 & $\mathrm{U}$ & 200000 \\
\hline 4-Chlorophenylphenyl ether & 200000 & $\mathrm{U}$ & 200000 & N-Nitroso-di-n- & 200000 & $\mathrm{U}$ & 200000 \\
\hline 4-Nitroaniline & 500000 & $\mathrm{U}$ & 500000 & N-Nitrosodiphenylamine & 250000 & & 200000 \\
\hline 4-Nitrophenol & 500000 & $\mathrm{U}$ & 500000 & Naphthalene & 1100000 & & 200000 \\
\hline Acenaphthene & 200000 & $\mathrm{U}$ & 200000 & Nitrobenzene & 200000 & $\mathrm{U}$ & 200000 \\
\hline Acenaphthylene & 200000 & $\mathrm{U}$ & 200000 & Pentachlorophenol & 500000 & $\mathrm{U}$ & 500000 \\
\hline Anthracene & 26000 & $\mathrm{~J}$ & 200000 & \begin{tabular}{|l} 
Phenanthrene \\
\end{tabular} & 430000 & & 200000 \\
\hline Benzo(a)anthracene & 200000 & $\mathrm{U}$ & 200000 & Phenol & 200000 & $\mathrm{U}$ & 200000 \\
\hline Benzo(a)pyrene & 200000 & $\mathrm{U}$ & 200000 & Pyrene & 17000 & $\mathrm{~J}$ & 200000 \\
\hline
\end{tabular}

\begin{tabular}{|c|c|c|c|c|c|c|}
\hline \multirow[t]{2}{*}{ Constituent } & \multicolumn{3}{|c|}{$\begin{array}{c}\text { J02636 } \\
\text { Sample Date 01/26/05 }\end{array}$} & \multicolumn{3}{|c|}{$\begin{array}{c}\text { J01PT8 } \\
\text { Sample Date 08/23/04 }\end{array}$} \\
\hline & $\mu g / L$ & $\mathbf{Q}$ & PQL & $\mu \mathrm{g} / \mathrm{L}$ & $\bar{Q}$ & PQL \\
\hline \multicolumn{7}{|c|}{ PCBs } \\
\hline Aroclor-1016 & 1 & $\mathrm{U}$ & 1 & 5 & $\mathrm{U}$ & 5 \\
\hline Aroclor-1221 & 1 & $U$ & 1 & 5 & $\mathrm{U}$ & 5 \\
\hline Aroclor- 1232 & 1 & $\mathrm{U}$ & 1 & 5 & $\bar{U}$ & 5 \\
\hline Aroclor-1242 & 1 & $\bar{U}$ & 1 & 5 & $\mathrm{U}$ & 5 \\
\hline Aroclor-1248 & 1 & $\mathrm{U}$ & 1 & 5 & $\mathrm{U}$ & 5 \\
\hline \begin{tabular}{|l|} 
Aroclor- 1254 \\
\end{tabular} & 1 & $\mathrm{U}$ & 1 & 5 & $\mathrm{U}$ & 5 \\
\hline Aroclor- 1260 & 1 & $U$ & 1 & 5 & $\mathrm{U}$ & 5 \\
\hline \multicolumn{7}{|c|}{ SVOAs } \\
\hline 1,2,4-Trichlorobenzene & 50 & UD & 50 & 50 & $\mathrm{U}$ & 50 \\
\hline 1,2-Dichlorobenzene & 50 & UD & 50 & 50 & $\mathrm{U}$ & 50 \\
\hline 1,3-Dichlorobenzene & 50 & UD & 50 & 50 & $\mathrm{U}$ & 50 \\
\hline 1,4-Dichlorobenzene & 50 & UD & 50 & 50 & $\mathrm{U}$ & 50 \\
\hline 2,4,5-Trichlorophenol & 120 & UD & 120 & 50 & $\mathrm{U}$ & 50 \\
\hline 2,4,6-Trichlorophenol & 50 & UD & 50 & 50 & $\mathrm{U}$ & 50 \\
\hline 2,4-Dichlorophenol & 50 & UD & 50 & 50 & $\mathrm{U}$ & 50 \\
\hline 2,4-Dimethylphenol & 50 & UD & 50 & 4 & $\mathrm{~J}$ & 50 \\
\hline 2,4-Dinitrophenol & 120 & UD & 120 & 50 & $\mathrm{U}$ & 50 \\
\hline
\end{tabular}


Table B-2. 600-233 Waste Characterization and In-Process Sampling Results.

\begin{tabular}{|c|c|c|c|c|c|c|}
\hline \multirow[t]{2}{*}{ Constituent } & \multicolumn{3}{|c|}{$\begin{array}{c}\text { J02636 } \\
\text { Sample Date 01/26/05 } \\
\end{array}$} & \multicolumn{3}{|c|}{$\begin{array}{c}\text { J01PT8 } \\
\text { Sample Date 08/23/04 } \\
\end{array}$} \\
\hline & $\mu \mathrm{g} / \mathrm{L}$ & $\mathbf{Q}$ & PQL & $\mu \mathrm{g} / \mathrm{L}$ & $\mathbf{Q}$ & PQL \\
\hline \multicolumn{7}{|c|}{ SVOAs (continued) } \\
\hline 2,4-Dinitrotoluene & 50 & UD & 50 & 50 & $\mathrm{U}$ & 50 \\
\hline 2,6-Dinitrotoluene & 50 & $\mathrm{UD}$ & 50 & 50 & $\mathrm{U}$ & 50 \\
\hline 2-Chloronaphthalene & 50 & UD & 50 & 50 & $\bar{U}$ & 50 \\
\hline 2-Chlorophenol & 50 & UD & 50 & 50 & $\mathrm{U}$ & 50 \\
\hline 2-Methylnaphthalene & 50 & UD & 50 & 50 & $\mathrm{U}$ & 50 \\
\hline 2-Methylphenol (cresol, o-) & 50 & UD & 50 & 50 & $\mathrm{U}$ & 50 \\
\hline 2-Nitroaniline & 120 & UD & 120 & 50 & $\mathrm{U}$ & 50 \\
\hline 2-Nitrophenol & 50 & UD & 50 & 50 & $\mathrm{U}$ & 50 \\
\hline 3+4 Methylphenol (cresol, $\mathrm{m}+\mathrm{p}$ ) & 9 & JD & 50 & 50 & $\mathrm{U}$ & 50 \\
\hline 3,3'-Dichlorobenzidine & 50 & UD & 50 & 50 & $\mathrm{U}$ & 50 \\
\hline 3-Nitroaniline & 120 & UD & 120 & 50 & $\mathrm{U}$ & 50 \\
\hline 4,6-Dinitro-2-methylphenol & 120 & UD & 120 & 50 & $\mathrm{U}$ & 50 \\
\hline 4-Bromophenylphenyl ether & 50 & $\mathrm{UD}$ & 50 & 50 & $\mathrm{U}$ & 50 \\
\hline 4-Chloro-3-methylphenol & 50 & UD & 50 & 50 & $\mathrm{U}$ & 50 \\
\hline 4-Chloroaniline & 50 & UD & 50 & 50 & $\mathrm{U}$ & 50 \\
\hline 4-Chlorophenylphenyl ether & 50 & $\mathrm{UD}$ & 50 & 50 & $\mathrm{U}$ & 50 \\
\hline 4-Nitroaniline & 120 & UD & 120 & 50 & $\mathrm{U}$ & 50 \\
\hline 4-Nitrophenol & 120 & UD & 120 & 50 & $\mathrm{U}$ & 50 \\
\hline Acenaphthene & 50 & UD & 50 & 50 & $\mathrm{U}$ & 50 \\
\hline Acenaphthylene & 50 & UD & 50 & 50 & $\mathrm{U}$ & 50 \\
\hline Anthracene & 50 & UD & 50 & 50 & $\mathrm{U}$ & 50 \\
\hline Benzo(a)anthracene & 50 & UD & 50 & 50 & $\mathrm{U}$ & 50 \\
\hline Benzo(a)pyrene & 50 & UD & 50 & 50 & $\mathrm{U}$ & 50 \\
\hline Benzo(b)fluoranthene & 50 & UD & 50 & 50 & $\mathrm{U}$ & 50 \\
\hline Benzo(ghi)perylene & 50 & UD & 50 & 50 & $\mathrm{U}$ & 50 \\
\hline Benzo(k)fluoranthene & 50 & UD & 50 & 50 & $\mathrm{U}$ & 50 \\
\hline Bis(2-chloro-1-methylethyl)ether & 50 & UD & 50 & 50 & $\mathrm{U}$ & 50 \\
\hline Bis(2-Chloroethoxy)methane & 50 & UD & 50 & 50 & $\mathrm{U}$ & 50 \\
\hline Bis(2-chloroethyl) ether & 50 & UD & 50 & 50 & $\mathrm{U}$ & 50 \\
\hline Bis(2-ethylhexyl) phthalate & 50 & UD & 50 & 8 & $\mathrm{JB}$ & 50 \\
\hline Butylbenzylphthalate & 50 & UD & 50 & 50 & $\mathrm{U}$ & 50 \\
\hline Carbazole & 50 & UD & 50 & 50 & $\mathrm{U}$ & 50 \\
\hline Chrysene & 50 & UD & 50 & 50 & $\mathrm{U}$ & 50 \\
\hline Di-n-butylphthalate & 50 & UD & 50 & 5 & $\mathrm{JB}$ & 50 \\
\hline Di-n-octylphthalate & 50 & UD & 50 & 50 & $\mathrm{U}$ & 50 \\
\hline Dibenz[a,h]anthracene & 50 & UD & 50 & 50 & $\mathrm{U}$ & 50 \\
\hline \begin{tabular}{|l|} 
Dibenzofuran \\
\end{tabular} & 50 & UD & 50 & 50 & $\mathrm{U}$ & 50 \\
\hline Diethylphthalate & 50 & UD & 50 & 50 & $\mathrm{U}$ & 50 \\
\hline Dimethyl phthalate & 50 & UD & 50 & 50 & $\mathrm{U}$ & 50 \\
\hline Fluoranthene & 50 & UD & 50 & 50 & $\mathrm{U}$ & 50 \\
\hline Fluorene & 50 & UD & 50 & 50 & $\mathrm{U}$ & 50 \\
\hline Hexachlorobenzene & 50 & UD & 50 & 50 & $\mathrm{U}$ & 50 \\
\hline Hexachlorobutadiene & 50 & UD & 50 & 50 & $\mathrm{U}$ & 50 \\
\hline Hexachlorocyclopentadiene & 50 & UD & 50 & 50 & $\mathrm{U}$ & 50 \\
\hline Hexachloroethane & 50 & UD & 50 & 50 & $\mathrm{U}$ & 50 \\
\hline Indeno(1,2,3-cd)pyrene & 50 & UD & 50 & 50 & $\mathrm{U}$ & 50 \\
\hline Isophorone & 50 & UD & 50 & 50 & $\mathrm{U}$ & 50 \\
\hline N-Nitroso-di-n-dipropylamine & 50 & UD & 50 & 28 & $\mathrm{~J}$ & 50 \\
\hline N-Nitrosodiphenylamine & 50 & UD & 50 & 50 & $\mathrm{U}$ & 50 \\
\hline Naphthalene & 50 & UD & 50 & 50 & $\mathrm{U}$ & 50 \\
\hline Nitrobenzene & 50 & UD & 50 & 50 & $\mathrm{U}$ & 50 \\
\hline Pentachlorophenol & 120 & UD & 120 & 50 & $\mathrm{U}$ & 50 \\
\hline Phenanthrene & 9 & JD & 50 & 50 & $U$ & 50 \\
\hline Phenol & 2 & JD & 50 & 50 & $\mathrm{U}$ & 50 \\
\hline Pyrene & 50 & UD & 50 & 50 & $\mathrm{U}$ & 50 \\
\hline
\end{tabular}


Table B-2. 600-233 Waste Characterization and In-Process Sampling Results. (6 Pages)

\begin{tabular}{|c|c|c|c|c|c|c|c|c|c|c|c|c|c|c|c|c|c|c|c|c|}
\hline \multirow{2}{*}{ Sample Location } & \multirow{2}{*}{$\begin{array}{c}\text { HEIS } \\
\text { Number }\end{array}$} & \multirow{2}{*}{$\begin{array}{c}\text { Sample } \\
\text { Date }\end{array}$} & \multicolumn{3}{|c|}{ 1,4-Dichlorobenzene } & \multicolumn{3}{|c|}{ 2,4,5-Trichlorophenol } & \multicolumn{3}{|c|}{ 2,4,6-Trichlorophenol } & \multicolumn{3}{|c|}{ 2,4-Dinitrotoluene } & \multicolumn{3}{|c|}{ 2-Methylphenol } & \multicolumn{3}{|c|}{ 3+4 Methylphenol } \\
\hline & & & $\mathrm{mg} / \mathrm{L}$ & $Q$ & PQL & $\mathrm{mg} / \mathrm{L}$ & $Q$ & PQL & $\mathrm{mg} / \mathrm{L}$ & $Q$ & PQL & $\mathrm{mg} / \mathrm{L}$ & $Q$ & PQL & $\mathrm{mg} / \mathrm{L}$ & Q & PQL & $\mathrm{mg} / \mathrm{L}$ & $Q$ & PQL \\
\hline $\begin{array}{l}2.5 \text {-in. pipe, dark gray } \\
\text { fine grain scale }\end{array}$ & J01ML5 & 08/23/04 & 0.05 & U & 0.05 & 0.12 & U & 0.12 & 0.05 & $\mathrm{U}$ & 0.05 & 0.05 & $U$ & 0.05 & 0.05 & U & 0.05 & 0.05 & $U$ & 0.05 \\
\hline $\begin{array}{l}\text { Soil impacted by leak } \\
\text { in } 2.5 \text {-in. pipe }\end{array}$ & J01PT9 & $08 / 23 / 04$ & 0.05 & $\mathrm{U}$ & 0.05 & 0.12 & $\mathrm{U}$ & 0.12 & 0.05 & $\mathrm{U}$ & 0.05 & 0.05 & $\mathrm{U}$ & 0.05 & 0.05 & $\mathrm{U}$ & 0.05 & 0.05 & $\mathrm{U}$ & 0.05 \\
\hline
\end{tabular}

\begin{tabular}{|c|c|c|c|c|c|c|c|c|c|c|c|c|c|c|c|c|c|c|c|c|}
\hline \multirow{2}{*}{ Sample Location } & \multirow{2}{*}{$\begin{array}{l}\text { HEIS } \\
\text { Number }\end{array}$} & \multirow{2}{*}{$\begin{array}{c}\text { Sample } \\
\text { Date }\end{array}$} & \multicolumn{3}{|c|}{ Hexachlorobenzene } & \multicolumn{3}{|c|}{ Hexachlorobutadiene } & \multicolumn{3}{|c|}{ Hexachloroethane } & \multicolumn{3}{|c|}{ Nitrobenzene } & \multicolumn{3}{|c|}{ Pentachlorophenol } & \multicolumn{3}{|c|}{ Pyridine } \\
\hline & & & $\mathrm{mg} / \mathrm{L}$ & $\bar{Q}$ & $\overline{\mathbf{P Q L}}$ & $\mathrm{mg} / \mathrm{L}$ & Q & $\mathbf{P Q L}$ & $\mathrm{mg} / \mathrm{L}$ & $Q$ & $\mathbf{P Q L}$ & $\mathrm{mg} / \mathrm{L}$ & Q & $\overline{\mathrm{PQL}}$ & $\mathrm{mg} / \mathrm{L}$ & $\mathbf{Q}$ & $\mathbf{P Q L}$ & $\mathrm{mg} / \mathrm{L}$ & $Q$ & $\mathbf{P Q L}$ \\
\hline $\begin{array}{l}2.5 \text {-in. pipe, dark gray } \\
\text { fine grain scale }\end{array}$ & J01ML5 & $08 / 23 / 04$ & 0.05 & U & 0.05 & 0.05 & $\mathrm{U}$ & 0.05 & 0.05 & U & 0.05 & 0.05 & $\mathrm{U}$ & 0.05 & 0.12 & $\mathrm{U}$ & 0.12 & 0.05 & $\mathrm{U}$ & 0.05 \\
\hline $\begin{array}{l}\text { Soil impacted by leak } \\
\text { in } 2.5 \text {-in. pipe }\end{array}$ & J01PT9 & $08 / 23 / 04$ & 0.05 & $\mathrm{U}$ & 0.05 & 0.05 & $\mathrm{U}$ & 0.05 & 0.05 & $\mathrm{U}$ & 0.05 & 0.05 & $\mathrm{U}$ & 0.05 & 0.12 & U & 0.12 & 0.05 & $\mathrm{U}$ & 0.05 \\
\hline
\end{tabular}

\begin{tabular}{|c|c|c|c|c|c|c|c|c|c|c|c|c|c|c|c|c|c|c|c|c|}
\hline \multirow{2}{*}{ Sample Location } & \multirow{2}{*}{$\begin{array}{c}\text { HEIS } \\
\text { Number }\end{array}$} & \multirow{2}{*}{$\begin{array}{l}\text { Sample } \\
\text { Date }\end{array}$} & \multicolumn{3}{|c|}{ Arsenic } & \multicolumn{3}{|c|}{ Barium } & \multicolumn{3}{|c|}{ Cadmium } & \multicolumn{3}{|c|}{ Chromium } & \multicolumn{3}{|c|}{ Lead } & \multicolumn{3}{|c|}{ Mercury } \\
\hline & & & $\mu \mathrm{g} / \mathrm{L}$ & $\mathbf{Q}$ & PQL & $\mu \mathrm{g} / \mathrm{L}$ & $\mathbf{Q}$ & PQL & $\mu \mathrm{g} / \mathrm{L}$ & $Q$ & $\mathrm{PQL}$ & $\mu \mathrm{g} / \mathrm{L}$ & $\mathbf{Q}$ & PQL & $\mu \mathrm{g} / \mathrm{L}$ & $\mathbf{Q}$ & PQL & $\mu \mathrm{g} / \mathrm{L}$ & Q & PQL \\
\hline $\begin{array}{l}2.5 \text {-in. pipe, dark gray } \\
\text { fine grain scale }\end{array}$ & J01ML5 & $08 / 23 / 04$ & 97.2 & U & 97.2 & 115 & & 13.2 & 14.4 & U & 14.4 & 19.6 & U & 19.6 & 132 & $U$ & 132 & 0.2 & U & 0.2 \\
\hline $\begin{array}{l}2.5 \text {-in. pipe, rusty water } \\
\text { like liquid }\end{array}$ & J01PT8 & $08 / 23 / 04$ & 50.7 & & 14.4 & 238 & & 39.6 & 30.2 & & 1.2 & 87.5 & & 2.4 & 14900 & & 7.6 & 0.2 & U & 0.2 \\
\hline $\begin{array}{l}\text { Muddy water-like } \\
\text { liquid (discovery } \\
\text { pipelines) }\end{array}$ & J02636 & $01 / 26 / 05$ & 580 & $\mathrm{U}$ & 580 & 2740 & & 40 & 80 & U & 80 & 14000 & & 80 & 72100 & & 380 & 1.7 & & 1 \\
\hline
\end{tabular}

\begin{tabular}{|l|c|c|c|c|c|c|c|c|}
\hline \multirow{2}{*}{ Sample Location } & \multirow{2}{*}{$\begin{array}{c}\text { HEIS } \\
\text { Number }\end{array}$} & $\begin{array}{c}\text { Sample } \\
\text { Date }\end{array}$ & \multicolumn{3}{|c|}{ Selenium } & \multicolumn{3}{c|}{ Silver } \\
\cline { 5 - 9 } & & $\mu \mathrm{g} / \mathrm{L}$ & $\mathrm{Q}$ & PQL & $\mu \mathrm{g} / \mathrm{L}$ & $\mathbf{Q}$ & PQL \\
\hline $\begin{array}{l}\text { 2.5-in. pipe, dark gray } \\
\text { fine grain scale }\end{array}$ & J01ML5 & $08 / 23 / 04$ & 167 & & 130 & 20 & $\mathrm{U}$ & 20 \\
\hline $\begin{array}{l}2.5 \text {-in. pipe, rusty water } \\
\text { like liquid }\end{array}$ & J01PT8 & $08 / 23 / 04$ & 118 & & 15.6 & 3.6 & $\mathrm{U}$ & 3.6 \\
\hline $\begin{array}{l}\text { Muddy water-like } \\
\text { liquid (discovery } \\
\text { pipelines) }\end{array}$ & J02636 & $01 / 26 / 05$ & 800 & $\mathrm{U}$ & 800 & 100 & $\mathrm{U}$ & 100 \\
\hline
\end{tabular}




\section{APPENDIX C \\ VERIFICATION SAMPLING RESULTS (3 Pages)}


Table C-1. 600-233 Verification Sampling Results. (3 Pages)

\begin{tabular}{|c|c|c|c|c|c|c|c|c|c|c|c|c|c|c|c|c|c|c|c|c|}
\hline \multirow{2}{*}{ Sample Location } & \multirow{2}{*}{$\begin{array}{c}\text { HEIS } \\
\text { Number }\end{array}$} & \multirow{2}{*}{$\begin{array}{c}\text { Sample } \\
\text { Date }\end{array}$} & \multicolumn{3}{|c|}{ Arsenic } & \multicolumn{3}{|c|}{ Barium } & \multicolumn{3}{|c|}{ Beryllium } & \multicolumn{3}{|c|}{ Boron } & \multicolumn{3}{|c|}{ Cadmium } & \multicolumn{3}{|c|}{ Chromium } \\
\hline & & & $\mathrm{mg} / \mathrm{kg}$ & $\mathbf{Q}$ & PQL & $\mathrm{mg} / \mathrm{kg}$ & $\mathbf{Q}$ & PQL & $\mathrm{mg} / \mathrm{kg}$ & Q & PQL & $\mathrm{mg} / \mathrm{kg}$ & $Q$ & PQL & $\mathrm{mg} / \mathrm{kg}$ & $Q$ & PQL & $\mathrm{mg} / \mathrm{kg}$ & $Q$ & PQL \\
\hline East End & J03WJ1 & $8 / 9 / 05$ & 2.5 & $\overrightarrow{\mathrm{U}}$ & 2.5 & 50.2 & $\mathrm{C}$ & 0.11 & 0.41 & & 0.06 & 1.5 & & 1.3 & 0.28 & $\mathrm{C}$ & 0.17 & 7.7 & $\mathrm{C}$ & 0.39 \\
\hline West End & J03WJ2 & $8 / 9 / 05$ & 2.5 & $\bar{U}$ & 2.5 & 51.2 & $\mathrm{C}$ & 0.11 & 0.35 & & 0.06 & 1.3 & $\mathrm{U}$ & 1.3 & 0.23 & $\mathrm{C}$ & 0.17 & 7.9 & $\mathrm{C}$ & 0.39 \\
\hline Duplicate of $\mathrm{J} 03 \mathrm{WJ} 2$ & $\mathrm{~J} 03 \mathrm{WJ} 3$ & $8 / 9 / 05$ & 2.5 & $\mathrm{U}$ & 2.5 & 46.5 & C & 0.11 & 0.27 & & 0.05 & 1.3 & $\mathrm{U}$ & 1.3 & 0.25 & $\mathrm{C}$ & 0.16 & 6.1 & C & 0.38 \\
\hline Equipment Blank & J03WJ4 & $8 / 9 / 05$ & 2.5 & $\mathrm{U}$ & 2.5 & 5.4 & $\mathrm{C}$ & 0.11 & 0.06 & $\mathrm{U}$ & 0.06 & 1.3 & $\mathrm{U}$ & 1.3 & 0.17 & UC & 0.17 & 0.77 & $\mathrm{C}$ & 0.39 \\
\hline
\end{tabular}

\begin{tabular}{|c|c|c|c|c|c|c|c|c|c|c|c|c|c|c|c|c|c|c|c|c|}
\hline \multirow{2}{*}{ Sample Location } & \multirow{2}{*}{$\begin{array}{c}\text { HEIS } \\
\text { Number }\end{array}$} & \multirow{2}{*}{$\begin{array}{c}\text { Sample } \\
\text { Date }\end{array}$} & \multicolumn{3}{|c|}{ Cobalt } & \multicolumn{3}{|c|}{ Copper } & \multicolumn{3}{|c|}{ Lead } & \multicolumn{3}{|c|}{ Manganese } & \multicolumn{3}{|c|}{ Mercury } & \multicolumn{3}{|c|}{ Molybdenum } \\
\hline & & & $\mathrm{mg} / \mathrm{kg}$ & Q & PQL & $\mathrm{mg} / \mathrm{kg}$ & Q & PQL & $\mathrm{mg} / \mathrm{kg}$ & $Q$ & PQL & $\mathrm{mg} / \mathrm{kg}$ & $\mathbf{Q}$ & PQL & $\mathrm{mg} / \mathrm{kg}$ & $\mathbf{Q}$ & PQL & $\mathrm{mg} / \mathrm{kg}$ & $\mathbf{Q}$ & PQL \\
\hline East End & J03WJ1 & $8 / 9 / 05$ & 6.3 & & 0.50 & 11.5 & $\mathrm{C}$ & 0.44 & 4.6 & $\mathrm{C}$ & 1.4 & 270 & C & 0.11 & 0.02 & $\mathrm{U}$ & 0.02 & 0.88 & $\mathrm{U}$ & 0.88 \\
\hline West End & J03WJ2 & $8 / 9 / 05$ & 5.3 & & 0.50 & 10.3 & $\mathrm{C}$ & 0.44 & 4.3 & $\mathrm{C}$ & 1.4 & 249 & $\mathrm{C}$ & 0.11 & 0.01 & $\mathrm{U}$ & 0.01 & 0.89 & $\mathrm{U}$ & 0.89 \\
\hline Duplicate of J03WJ2 & J03WJ3 & $8 / 9 / 05$ & 4.9 & & 0.49 & 9.8 & $\mathrm{C}$ & 0.44 & 4.9 & $\mathrm{C}$ & 1.4 & 223 & $\mathrm{C}$ & 0.11 & 0.02 & $\overline{\mathrm{U}}$ & 0.02 & 0.87 & $\mathrm{U}$ & 0.87 \\
\hline Equipment Blank & J03WJ4 & $8 / 9 / 05$ & 0.50 & $\mathrm{U}$ & 0.50 & 1.4 & $\mathrm{C}$ & 0.44 & 1.7 & $\mathrm{C}$ & 1.4 & 17.5 & $\mathrm{C}$ & 0.11 & 0.01 & $\mathrm{U}$ & 0.01 & 0.89 & $\mathrm{U}$ & 0.89 \\
\hline
\end{tabular}

\begin{tabular}{|c|c|c|c|c|c|c|c|c|c|c|c|c|c|c|c|c|c|c|c|c|}
\hline \multirow{2}{*}{ Sample Location } & \multirow{2}{*}{$\begin{array}{c}\text { HEIS } \\
\text { Number }\end{array}$} & \multirow{2}{*}{$\begin{array}{l}\text { Sample } \\
\text { Date }\end{array}$} & \multicolumn{3}{|c|}{ Nickel } & \multicolumn{3}{|c|}{ Selenium } & \multicolumn{3}{|c|}{ Silver } & \multicolumn{3}{|c|}{ Vanadium } & \multicolumn{3}{|c|}{ Zinc } & \multicolumn{3}{|c|}{ TPH } \\
\hline & & & $\mathrm{mg} / \mathrm{kg}$ & $\mathbf{Q}$ & PQL & $\mathrm{mg} / \mathrm{kg}$ & $\mathbf{Q}$ & PQL & $\mathrm{mg} / \mathrm{kg}$ & Q & PQL & $\mathrm{mg} / \mathrm{kg}$ & $\mathbf{Q}$ & PQL & $\mathrm{mg} / \mathrm{kg}$ & $\mathbf{Q}$ & PQL & $\mathrm{mg} / \mathrm{kg}$ & $Q$ & PQL \\
\hline East End & J03WJ1 & $8 / 9 / 05$ & 8.3 & & 1.2 & 3.0 & $\mathrm{C}$ & 2.7 & 0.50 & $\mathrm{U}$ & 0.50 & 37.0 & & 0.33 & 33.8 & & 0.28 & 133 & $U$ & 133 \\
\hline West End & $\mathrm{J} 03 \mathrm{WJ} 2$ & $8 / 9 / 05$ & 7.7 & & 1.2 & 2.7 & $\mathrm{UC}$ & 2.7 & 0.50 & $\mathrm{U}$ & 0.50 & 34.5 & & 0.33 & 30.7 & & 0.28 & 132 & $\mathrm{U}$ & 132 \\
\hline Duplicate of J03WJ2 & J03WJ3 & $8 / 9 / 05$ & 7.4 & & 1.2 & 2.7 & $\mathrm{UC}$ & 2.7 & 0.49 & $\mathrm{U}$ & 0.49 & 25.3 & & 0.33 & 28.5 & & 0.27 & 132 & $\mathrm{U}$ & 132 \\
\hline Equipment Blank & J03WJ4 & $8 / 9 / 05$ & 1.2 & $\bar{U}$ & 1.2 & 2.7 & $\mathrm{UC}$ & 2.7 & 0.50 & $\mathrm{U}$ & 0.50 & 0.33 & $\mathrm{U}$ & 0.33 & 3.2 & & 0.28 & & & \\
\hline
\end{tabular}

Note: Data qualified with $\mathrm{B}, \mathrm{C}$, and/or J, are considered acceptable values.

$\mathrm{B}=$ blank contamination

$\mathrm{PQL}=$ practical quantitation limit

$\mathrm{C}=$ blank contamination

$\mathrm{Q}=$ qualifier

HEIS = Hanford Environmental Information System

$\mathrm{U}=$ undetected

$\mathrm{J}=$ estimate 
Table C-1. 600-233 Verification Sampling Results. (3 Pages)

\begin{tabular}{|c|c|c|c|c|c|c|c|c|c|c|c|c|}
\hline \multirow[t]{2}{*}{ Constituent } & \multicolumn{3}{|c|}{$\begin{array}{c}\text { J03WJ1 } \\
\text { East End } \\
\text { Sample Date 8/9/05 }\end{array}$} & \multicolumn{3}{|c|}{$\begin{array}{c}\text { J03WJ2 } \\
\text { West End } \\
\text { Sample Date 8/9/05 }\end{array}$} & \multicolumn{3}{|c|}{$\begin{array}{c}\text { J03WJ3 } \\
\text { Duplicate of J03WJ2 } \\
\text { Sample Date } 8 / 9 / 05\end{array}$} & \multicolumn{3}{|c|}{$\begin{array}{c}\text { J03WJ4 } \\
\text { Equipment Blank } \\
\text { Sample Date 8/9/05 }\end{array}$} \\
\hline & $\mu \mathrm{g} / \mathrm{kg}$ & $\mathbf{Q}$ & PQL & $\mu \mathrm{g} / \mathrm{kg}$ & $\mathbf{Q}$ & $\mathbf{P Q L}$ & $\mu \mathrm{g} / \mathrm{kg}$ & $\mathbf{Q}$ & PQL & $\mu \mathrm{g} / \mathrm{kg}$ & $\mathbf{Q}$ & PQL \\
\hline \multicolumn{13}{|c|}{ Polychlorinated Biphenyls } \\
\hline Aroclor-1016 & 13 & $\mathrm{U}$ & 13 & 13 & $\mathrm{U}$ & 13 & 13 & $\mathrm{U}$ & 13 & & & \\
\hline Aroclor-1221 & 13 & $\bar{U}$ & 13 & 13 & $\bar{U}$ & 13 & 13 & $\bar{U}$ & 13 & & & \\
\hline Aroclor-1232 & 13 & $\mathrm{U}$ & 13 & 13 & $\mathrm{U}$ & 13 & 13 & $\mathrm{U}$ & 13 & & & \\
\hline Aroclor-1242 & 13 & $\mathrm{U}$ & 13 & 13 & $\mathrm{U}$ & 13 & 13 & $\mathrm{U}$ & 13 & & & \\
\hline Aroclor-1248 & 13 & $\mathrm{U}$ & 13 & 13 & $\mathrm{U}$ & 13 & 13 & $\mathrm{U}$ & 13 & & & \\
\hline Aroclor-1254 & 13 & $\bar{U}$ & 13 & 13 & $\bar{U}$ & 13 & 13 & $\overline{\mathrm{U}}$ & 13 & & & \\
\hline Aroclor-1260 & 13 & $\mathrm{U}$ & 13 & 13 & $\mathrm{U}$ & 13 & 13 & $\mathrm{U}$ & 13 & & & \\
\hline \multicolumn{13}{|c|}{ Semivolatile Organic Analytes } \\
\hline 1,2,4-Trichlorobenzene & 330 & $U$ & 330 & 330 & $\mathrm{U}$ & 330 & 330 & $U$ & 330 & 330 & $\mathrm{U}$ & 330 \\
\hline 1,2-Dichlorobenzene & 330 & $\mathrm{U}$ & 330 & 330 & $\bar{U}$ & 330 & 330 & $\mathrm{U}$ & 330 & 330 & $\mathrm{U}$ & 330 \\
\hline 1,3-Dichlorobenzene & 330 & $\mathrm{U}$ & 330 & 330 & $\mathrm{U}$ & 330 & 330 & $\mathrm{U}$ & 330 & 330 & $\mathrm{U}$ & 330 \\
\hline 1,4-Dichlorobenzene & 330 & $\mathrm{U}$ & 330 & 330 & $\mathrm{U}$ & 330 & 330 & $\mathrm{U}$ & 330 & 330 & $\mathrm{U}$ & 330 \\
\hline 2,4,5-Trichlorophenol & 830 & $\mathrm{U}$ & 830 & 830 & $\mathrm{U}$ & 830 & 830 & $U$ & 830 & 830 & $\mathrm{U}$ & 830 \\
\hline 2,4,6-Trichlorophenol & 830 & $\mathrm{U}$ & 830 & 830 & $\mathrm{U}$ & 830 & 830 & $\mathrm{U}$ & 830 & 830 & $\mathrm{U}$ & 830 \\
\hline 2,4-Dichlorophenol & 330 & $\mathrm{U}$ & 330 & 330 & $\mathrm{U}$ & 330 & 330 & $\mathrm{U}$ & 330 & 330 & $\mathrm{U}$ & 330 \\
\hline 2,4-Dimethylphenol & 330 & $\mathrm{U}$ & 330 & 330 & $\mathrm{U}$ & 330 & 330 & $\mathrm{U}$ & 330 & 330 & $\mathrm{U}$ & 330 \\
\hline 2,4-Dinitrophenol & 830 & $\mathrm{U}$ & 830 & 830 & $\mathrm{U}$ & 830 & 830 & $\overline{\mathrm{U}}$ & 830 & 830 & $\mathrm{U}$ & 830 \\
\hline 2,4-Dinitrotoluene & 330 & $\mathrm{U}$ & 330 & 330 & $\mathrm{U}$ & 330 & 330 & $\bar{U}$ & 330 & 330 & $\mathrm{U}$ & 330 \\
\hline 2,6-Dinitrotoluene & 330 & $\mathrm{U}$ & 330 & 330 & $\mathrm{U}$ & 330 & 330 & $\overline{\mathrm{U}}$ & 330 & 330 & $\mathrm{U}$ & 330 \\
\hline 2-Chloronaphthalene & 330 & $\mathrm{U}$ & 330 & 330 & $\mathrm{U}$ & 330 & 330 & $\mathrm{U}$ & 330 & 330 & $\mathrm{U}$ & 330 \\
\hline 2-Chlorophenol & 330 & $\mathrm{U}$ & 330 & 330 & $\mathrm{U}$ & 330 & 330 & $\mathrm{U}$ & 330 & 330 & $\mathrm{U}$ & 330 \\
\hline 2-Methylnaphthalene & 330 & $\mathrm{U}$ & 330 & 330 & $\mathrm{U}$ & 330 & 330 & $\mathrm{U}$ & 330 & 330 & $U$ & 330 \\
\hline 2-Methylphenol (cresol, o-) & 330 & $\mathrm{U}$ & 330 & 330 & $\mathrm{U}$ & 330 & 330 & $\mathrm{U}$ & 330 & 330 & $U$ & 330 \\
\hline 2-Nitroaniline & 830 & $\mathrm{U}$ & 830 & 830 & $\mathrm{U}$ & 830 & 830 & $\bar{U}$ & 830 & 830 & $\mathrm{U}$ & 830 \\
\hline 2-Nitrophenol & 330 & $\mathrm{U}$ & 330 & 330 & $\mathrm{U}$ & 330 & 330 & $\mathrm{U}$ & 330 & 330 & $U$ & 330 \\
\hline 3+4 Methylphenol (cresol, $m+p)$ & 330 & $\mathrm{U}$ & 330 & 330 & $\mathrm{U}$ & 330 & 330 & $\mathrm{U}$ & 330 & 330 & $\mathrm{U}$ & 330 \\
\hline 3,3'-Dichlorobenzidine & 330 & $\mathrm{U}$ & 330 & 330 & U & 330 & 330 & $\mathrm{U}$ & 330 & 330 & $\mathrm{U}$ & 330 \\
\hline 3-Nitroaniline & 830 & $\mathrm{U}$ & 830 & 830 & $U$ & 830 & 830 & $\mathrm{U}$ & 830 & 830 & $\mathrm{U}$ & 830 \\
\hline 4,6-Dinitro-2-methylphenol & 830 & $\mathrm{U}$ & 830 & 830 & $\mathrm{U}$ & 830 & 830 & $\mathrm{U}$ & 830 & 830 & $\mathrm{U}$ & 830 \\
\hline 4-Bromophenylphenyl ether & 330 & $\mathrm{U}$ & 330 & 330 & $U$ & 330 & 330 & $\mathrm{U}$ & 330 & 330 & $\mathrm{U}$ & 330 \\
\hline 4-Chloro-3-methylphenol & 330 & $\mathrm{U}$ & 330 & 330 & $U$ & 330 & 330 & $\mathrm{U}$ & 330 & 330 & U & 330 \\
\hline 4-Chloroaniline & 330 & $\mathrm{U}$ & 330 & 330 & $\mathrm{U}$ & 330 & 330 & $\mathrm{U}$ & 330 & 330 & $\mathrm{U}$ & 330 \\
\hline 4-Chlorophenylphenyl ether & 330 & $\mathrm{U}$ & 330 & 330 & U & 330 & 330 & $\mathrm{U}$ & 330 & 330 & $\mathrm{U}$ & 330 \\
\hline 4-Nitroaniline & 830 & $\mathrm{U}$ & 830 & 830 & $\mathrm{U}$ & 830 & 830 & $\mathrm{U}$ & 830 & 830 & $\mathrm{U}$ & 830 \\
\hline 4-Nitrophenol & 830 & $\mathrm{U}$ & 830 & 830 & $U$ & 830 & 830 & $\mathrm{U}$ & 830 & 830 & $\mathrm{U}$ & 830 \\
\hline Acenaphthene & 330 & $\mathrm{U}$ & 330 & 330 & $\mathrm{U}$ & 330 & 330 & $\mathrm{U}$ & 330 & 330 & $\mathrm{U}$ & 330 \\
\hline Acenaphthylene & 330 & $\mathrm{U}$ & 330 & 330 & $\mathrm{U}$ & 330 & 330 & $\mathrm{U}$ & 330 & 330 & $\mathrm{U}$ & 330 \\
\hline Anthracene & 330 & $\mathrm{U}$ & 330 & 47 & $\mathrm{~J}$ & 330 & 330 & $\mathrm{U}$ & 330 & 330 & $\mathrm{U}$ & 330 \\
\hline Benzo(a)anthracene & 18 & $\mathrm{~J}$ & 330 & 290 & $\mathrm{~J}$ & 330 & 84 & $\mathrm{~J}$ & 330 & 330 & $\mathrm{U}$ & 330 \\
\hline Benzo(a)pyrene & 330 & $\mathrm{U}$ & 330 & 180 & $\mathrm{~J}$ & 330 & 63 & $\mathrm{~J}$ & 330 & 330 & $\mathrm{U}$ & 330 \\
\hline Benzo(b)fluoranthene & 330 & $\mathrm{U}$ & 330 & 220 & $\mathrm{JB}$ & 330 & 660 & $\mathrm{U}$ & 660 & 330 & $\mathrm{U}$ & 330 \\
\hline Benzo $(\mathrm{g}, \mathrm{h}, \mathrm{i})$ perylene & 330 & $\mathrm{U}$ & 330 & 660 & $\mathrm{U}$ & 660 & 660 & $\mathrm{U}$ & 660 & 330 & $\mathrm{U}$ & 330 \\
\hline Benzo(k)fluoranthene & 660 & $\mathrm{U}$ & 660 & 180 & $\mathrm{JB}$ & 330 & 660 & $\mathrm{U}$ & 660 & 330 & $\mathrm{U}$ & 330 \\
\hline Bis(2-chloro-1-methylethyl)ether & 330 & $\mathrm{U}$ & 330 & 330 & $\mathrm{U}$ & 330 & 330 & $\mathrm{U}$ & 330 & 330 & $\mathrm{U}$ & 330 \\
\hline Bis(2-Chloroethoxy)methane & 330 & $\mathrm{U}$ & 330 & 330 & $\mathrm{U}$ & 330 & 330 & $\mathrm{U}$ & 330 & 330 & $\mathrm{U}$ & 330 \\
\hline Bis(2-chloroethyl) ether & 330 & $\mathrm{U}$ & 330 & 330 & $\mathrm{U}$ & 330 & 330 & $\mathrm{U}$ & 330 & 330 & $\mathrm{U}$ & 330 \\
\hline Bis(2-ethylhexyl) phthalate & 660 & $\mathrm{U}$ & 660 & 660 & $\mathrm{U}$ & 660 & 660 & $\mathrm{U}$ & 660 & 660 & $\mathrm{U}$ & 660 \\
\hline Butylbenzylphthalate & 330 & $\mathrm{U}$ & 330 & 28 & $\mathrm{~J}$ & 330 & 330 & $\mathrm{U}$ & 330 & 330 & $\mathrm{U}$ & 330 \\
\hline
\end{tabular}


Table C-1. 600-233 Verification Sampling Results. (3 Pages)

\begin{tabular}{|c|c|c|c|c|c|c|c|c|c|c|c|c|}
\hline \multirow[t]{2}{*}{ Constituent } & \multicolumn{3}{|c|}{$\begin{array}{c}\text { J03WJ1 } \\
\text { East End } \\
\text { Sample Date 8/9/05 }\end{array}$} & \multicolumn{3}{|c|}{$\begin{array}{c}\text { J03WJ2 } \\
\text { West End } \\
\text { Sample Date 8/9/05 }\end{array}$} & \multicolumn{3}{|c|}{$\begin{array}{c}\text { J03WJ3 } \\
\text { Duplicate of J03WJ2 } \\
\text { Sample Date 8/9/05 }\end{array}$} & \multicolumn{3}{|c|}{$\begin{array}{c}\text { J03WJ4 } \\
\text { Equipment Blank } \\
\text { Sample Date 8/9/05 }\end{array}$} \\
\hline & $\mu \mathrm{g} / \mathrm{kg}$ & $\mathbf{Q}$ & PQL & $\mu \mathrm{g} / \mathrm{kg}$ & $\mathbf{Q}$ & PQL & $\mu \mathrm{g} / \mathrm{kg}$ & $\mathbf{Q}$ & PQL & $\mu \mathrm{g} / \mathrm{kg}$ & $\mathbf{Q}$ & PQL \\
\hline \multicolumn{13}{|c|}{ Semivolatile Organic Analytes (continued) } \\
\hline Carbazole & 330 & $\mathrm{U}$ & 330 & 330 & U & 330 & 330 & $\mathrm{U}$ & 330 & 330 & $\mathrm{U}$ & 330 \\
\hline Chrysene & 22 & $\mathrm{~J}$ & 330 & 340 & & 330 & 100 & $\mathrm{~J}$ & 100 & 330 & $\mathrm{U}$ & 330 \\
\hline Di-n-butylphthalate & 330 & $\mathrm{U}$ & 330 & 660 & $\mathrm{U}$ & 660 & 660 & $\mathrm{U}$ & 660 & 380 & $\mathrm{~B}$ & 330 \\
\hline Di-n-octylphthalate & 330 & $\mathrm{U}$ & 330 & 330 & $\mathrm{U}$ & 330 & 330 & $\mathrm{U}$ & 330 & 330 & $\mathrm{U}$ & 330 \\
\hline Dibenz(a,h)anthracene & 330 & $\mathrm{U}$ & 330 & 61 & $J$ & 330 & 25 & $\mathrm{~J}$ & 330 & 330 & $\mathrm{U}$ & 330 \\
\hline Dibenzofuran & 330 & $\mathrm{U}$ & 330 & 330 & $\mathrm{U}$ & 330 & 330 & $\mathrm{U}$ & 330 & 330 & $\mathrm{U}$ & 330 \\
\hline Diethylphthalate & 330 & $\mathrm{U}$ & 330 & 330 & $\mathrm{U}$ & 330 & 330 & $\mathrm{U}$ & 330 & 330 & $\mathrm{U}$ & 330 \\
\hline Dimethyl phthalate & 330 & $\mathrm{U}$ & 330 & 330 & $\mathrm{U}$ & 330 & 330 & $\mathrm{U}$ & 330 & 330 & $\mathrm{U}$ & 330 \\
\hline Fluoranthene & 27 & $\mathrm{~J}$ & 330 & 690 & & 330 & 140 & $\mathrm{~J}$ & 330 & 330 & $U$ & 330 \\
\hline Fluorene & 330 & $\mathrm{U}$ & 330 & 330 & $\mathrm{U}$ & 330 & 330 & $\mathrm{U}$ & 330 & 330 & $\mathrm{U}$ & 330 \\
\hline Hexachlorobenzene & 330 & $\mathrm{U}$ & 330 & 330 & $\mathrm{U}$ & 330 & 330 & $\mathrm{U}$ & 330 & 330 & $\mathrm{U}$ & 330 \\
\hline Hexachlorobutadiene & 330 & $\mathrm{U}$ & 330 & 330 & $U$ & 330 & 330 & $U$ & 330 & 330 & $\mathrm{U}$ & 330 \\
\hline Hexachlorocyclopentadiene & 330 & $\mathrm{U}$ & 330 & 330 & $\mathrm{U}$ & 330 & 330 & $\mathrm{U}$ & 330 & 330 & $\mathrm{U}$ & 330 \\
\hline Hexachloroethane & 330 & $\mathrm{U}$ & 330 & 330 & $\mathrm{U}$ & 330 & 330 & $\mathrm{U}$ & 330 & 330 & $\mathrm{U}$ & 330 \\
\hline Indeno(1,2,3-cd)pyrene & 330 & $\mathrm{U}$ & 330 & 110 & $\mathrm{JB}$ & 330 & 660 & $\mathrm{U}$ & 660 & 330 & $\mathrm{U}$ & 330 \\
\hline Isophorone & 330 & $\mathrm{U}$ & 330 & 330 & $\mathrm{U}$ & 330 & 330 & $\mathrm{U}$ & 330 & 330 & $\mathrm{U}$ & 330 \\
\hline N-Nitroso-di-n-dipropylamine & 330 & $\mathrm{U}$ & 330 & 330 & $\mathrm{U}$ & 330 & 330 & $\mathrm{U}$ & 330 & 330 & $U$ & 330 \\
\hline N-Nitrosodiphenylamine & 330 & $\mathrm{U}$ & 330 & 330 & $\mathrm{U}$ & 330 & 330 & $\mathrm{U}$ & 330 & 330 & $\mathrm{U}$ & 330 \\
\hline Naphthalene & 330 & $\mathrm{U}$ & 330 & 330 & $\mathrm{U}$ & 330 & 330 & $\mathrm{U}$ & 330 & 330 & $\mathrm{U}$ & 330 \\
\hline Nitrobenzene & 330 & $\mathrm{U}$ & 330 & 330 & $\mathrm{U}$ & 330 & 330 & $\mathrm{U}$ & 330 & 330 & $\mathrm{U}$ & 330 \\
\hline Pentachlorophenol & 830 & $\mathrm{U}$ & 830 & 830 & $\mathrm{U}$ & 830 & 830 & $\mathrm{U}$ & 830 & 830 & $\mathrm{U}$ & 830 \\
\hline Phenanthrene & 330 & $\mathrm{U}$ & 330 & 340 & & 330 & 37 & $\mathrm{~J}$ & 330 & 330 & $\mathrm{U}$ & 330 \\
\hline Phenol & 330 & $\mathrm{U}$ & 330 & 330 & $\mathrm{U}$ & 330 & 330 & $\mathrm{U}$ & 330 & 330 & $\mathrm{U}$ & 330 \\
\hline Pyrene & 23 & $\mathrm{~J}$ & 330 & 510 & & 330 & 120 & $\mathrm{~J}$ & 330 & 330 & $\mathrm{U}$ & 330 \\
\hline
\end{tabular}




\section{APPENDIX D \\ CALCULATION OF HAZARD QUOTIENTS AND \\ EXCESS CARCINOGENIC RISK \\ (4 Pages)}




\section{CALCULATION COVER SHEET}

Project Title $100-\mathrm{B} / \mathrm{C}$ Field Remediation

Job No. 14655

\section{Area 600}

Discipline Environmental

*Calc. No. 0600X-CA-V0054

Subject 600-233 Waste Site Hazard Quotient and Carcinogenic Risk Calculations

Computer Program Excel

Program No. Excel 2003

The attached calculations have been generated to document compliance with established cleanup levels. These documents should be used in conjunction with other relevant documents in the administrative record.

\section{Committed Calculation $\otimes \quad$ Preliminary $\square \quad$ Superseded $\square \quad$ Voided $\square$}

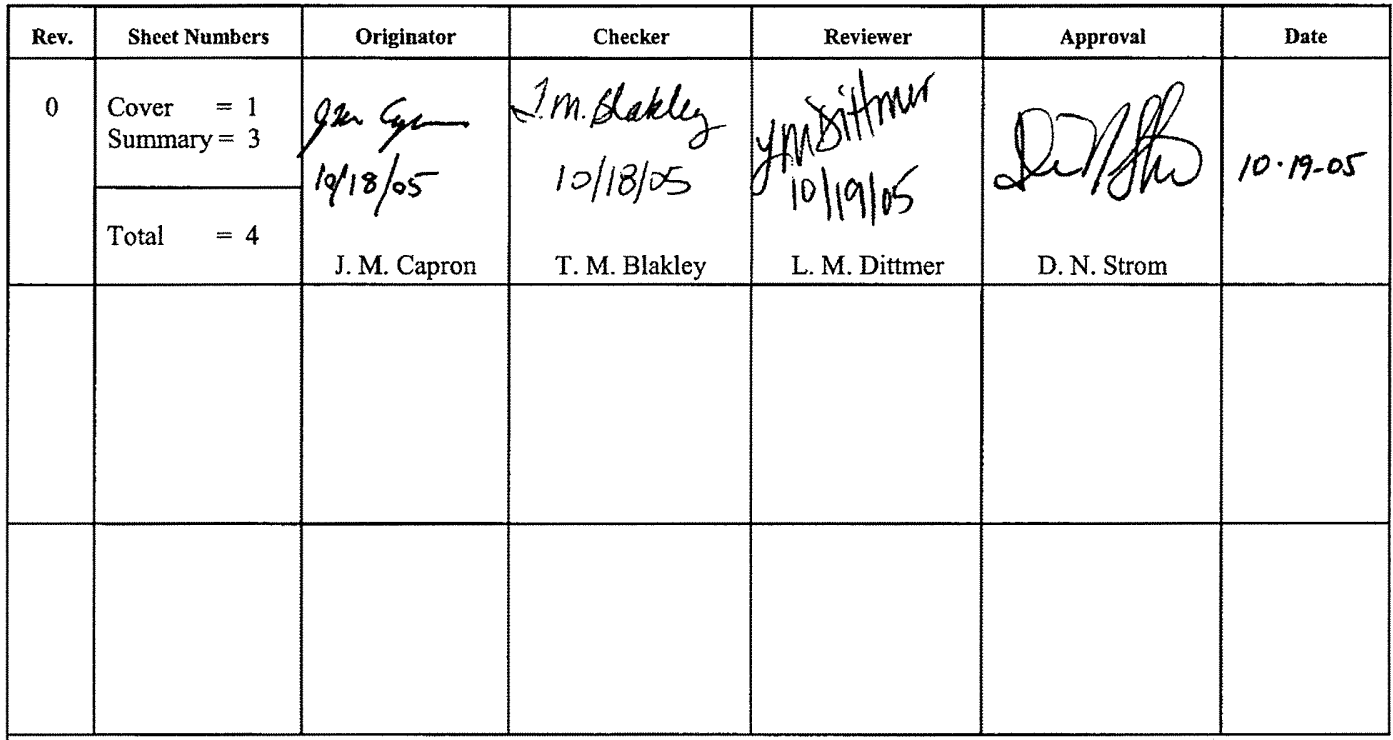

SUMMARY OF REVISION

\begin{tabular}{|l|l|}
\hline & \\
\hline & \\
&
\end{tabular}

*Obtain Calc. No. from DIS

DE01437.03 (12/09/2004) 
Washington Closure Hanford CALCULATION SHEET

\begin{tabular}{|r|l|r|c|c|c|c|c|}
\hline Originator: & J. M. Capron feme & Date: & $10 / 18 / 05$ & Calc. No.: & $0600 X$-CA-V0054 & Rev.: & 0 \\
\hline Project: & 100 -B/C Field Zemediation & Job No: & 14655 & Checked: & T. M. Blakley $/ \mathrm{m} 3$ & Date: & $10 / 18 / 55$ \\
\hline Subject: & $600-233$ Waste Site Hazard Quotient and Carcinogenic Risk Calculations & Sheet No. 1 of 3 \\
\hline
\end{tabular}

\section{PURPOSE:}

Provide documentation to support the calculation of the hazard quotient (HQ) and carcinogenic (excess cancer) risk values for the 600-233 Waste Site Remaining Sites Verification Package (WCH 2005). In accordance with the remedial action goals (RAGs) in the remedial design report/remedial action work plan (RDR/RAWP) (DOE-RL 2005), the following criteria must be met:

1) An HQ of $<1.0$ for all individual noncarcinogens

2) A cumulative $H Q$ of $<1.0$ for noncarcinogens

3) An excess cancer risk of $<1 \times 10^{-6}$ for individual carcinogens

4) A cumulative excess cancer risk of $<1 \times 10^{-5}$ for carcinogens.

\section{GIVEN/REFERENCES:}

1) DOE-RL, 2005, Remedial Design Report/Remedial Action Work Plan for the 100 Areas, DOE/RL-96-17, Rev. 5, U.S. Department of Energy, Richland Operations Office, Richland, Washington.

2) WAC 173-340, "Model Toxics Control Act - Cleanup," Washington Administrative Code, 1996.

3) WCH, 2005, Waste Site Reclassification Form 2005-041, and Attachment Remaining Sites Verification Package for the 600-233 Waste Site, Vertical Pipe Near 100-B Electrical Laydown Area, Washington Closure Hanford, LLC, Richland, Washington.

\section{SOLUTION:}

1) Calculate an HQ for each noncarcinogenic constituent detected above background or required detection limit/practical quantitation limit and compare it to the individual HQ criterion of $<1.0$ (DOE-RL 2005).

2) Sum the HQs and compare to the cumulative HQ criterion of $<1.0$.

3) Calculate an excess cancer risk value for each carcinogenic constituent detected above background or required detection limit/practical quantitation limit and compare it to the individual excess cancer risk criterion of $<1 \times 10^{-6}$ (DOE-RL 2005).

4) Sum the excess cancer risk values and compare to the cumulative cancer risk criterion of $<1 \times 10^{-5}$. 
Washington Closure Hanford

\begin{tabular}{r|l|r|c|c|c|c|c|c|}
\hline Project: & $100-B / C$ Field Remediation & Job No: & 14655 & Checked: & T. M. Blaklex Im/3 & Date: & $10 / 18 / 05$ \\
\hline
\end{tabular}

\begin{tabular}{l|l|l} 
Subject: & $600-233$ Waste Site Hazard Quotient and Carcinogenic Risk Calculations & Sheet No. 2 of 3
\end{tabular}

\section{METHODOLOGY:}

Hazard quotient and carcinogenic risk calculations were computed using the maximum value for each analyte in the verification data set (WCH 2005). Of the contaminants of concern and contaminants of potential concern for the site, boron requires the HQ and risk calculations because it was detected and a Washington State or Hanford Site background value is not available. Selenium is included because the maximum detected concentration for this analyte was above its Washington State background value. Multiple semivolatile organic analytes (as shown in Table 1, below) are included because they were detected by laboratory analysis and cannot be attributed to natural occurrence. An example of the HQ and risk calculations is presented below:

1) For example, the maximum value for boron is $1.5 \mathrm{mg} / \mathrm{kg}$, divided by the noncarcinogenic $\mathrm{RAG}$ value of $16,000 \mathrm{mg} / \mathrm{kg}$ (boron is identified as a noncarcinogen in WAC 173-340-740[3]), is $9.4 \times 10^{-5}$. Comparing this value, and all other individual values, to the requirement of $<1.0$, this criterion is met.

2) After the HQ calculations are completed for the appropriate analytes, the cumulative HQ is obtained by summing the individual values. (To avoid errors due to intermediate rounding, the individual $\mathrm{HQ}$ values prior to rounding are used for this calculation.) The sum of the HQ values is $8.0 \times 10^{-3}$. Comparing this value to the requirement of $<1.0$, this criterion is met.

3) To calculate the excess cancer risk, the maximum value is divided by the carcinogenic RAG value, then multiplied by $1 \times 10^{-6}$. For example, the maximum value for benzo(a)anthracene is $0.29 \mathrm{mg} / \mathrm{kg}$; divided by $1.37 \mathrm{mg} / \mathrm{kg}$ and multiplied as indicated is $2.1 \times 10^{-7}$. Comparing this value, and all other individual values, to the requirement of $<1 \times 10^{-6}$, this criterion is met.

4) After these calculations are completed for the carcinogenic analytes, the cumulative excess cancer risk can be obtained by summing the individual values. (To avoid errors due to intermediate rounding, the individual excess carcinogenic risk values prior to rounding are used for this calculation.) The sum of the excess cancer risk values for the $600-233$ site is $2.2 \times 10^{-6}$. Comparing this value to the requirement of $<1 \times 10^{-5}$, this criterion is met.

\section{RESULTS:}

1) List individual noncarcinogens and corresponding HQs $>1.0$ : None

2) List the cumulative noncarcinogenic $H Q>1.0$ : None

3) List individual carcinogens and corresponding excess cancer risk $>1 \times 10^{-6}$ : None

4) List the cumulative excess cancer risk for carcinogens $>1 \times 10^{-5}$ : None.

Table 1 shows the results of the calculations for the $600-233$ site. 
Washington Closure Hanford

CALCULATION SHEET

\begin{tabular}{|c|c|c|c|c|c|c|c|}
\hline Originator: & J.M. Capron & Date: & $10 / 18 / 05$ & Calc. No.: & $0600 \mathrm{X}-\mathrm{CA}-\mathrm{V} 0054$ & Rev.: & 0 \\
\hline Project: & 100-B/C Field Remediation & Job No: & 14655 & Checked: & T.M. Blakley $\ln \beta$ & Date: & $10 / 18 / 05$ \\
\hline Subject: & \multicolumn{5}{|c|}{ 600-233 Waste Site Hazard Quotient and Carcinogenic Risk Calculations } & \multicolumn{2}{|c|}{ Sheet No. 3 of 3} \\
\hline
\end{tabular}

1

2

3

4

5

6

7

8

10

11

12

13

14

15

16

17

18

19

20

21

22

23

24

Table 1. Hazard Quotient and Excess Cancer Risk Results for the 600-233 Site.

\begin{tabular}{|c|c|c|c|c|c|}
\hline $\begin{array}{l}\text { Contaminants of Concern/ } \\
\text { Contaminants of Potential Concern }\end{array}$ & $\begin{array}{c}\text { Maximum } \\
\text { Value } \\
\text { (mg/kg) }\end{array}$ & $\begin{array}{c}\text { Noncarcinogen } \\
\text { RAG }^{b} \\
(\mathrm{mg} / \mathrm{kg})\end{array}$ & $\begin{array}{l}\text { Hazard } \\
\text { Quotient }\end{array}$ & $\begin{array}{c}\text { Carcinogen } \\
\text { RAG }^{\mathrm{b}} \\
(\mathrm{mg} / \mathrm{kg})\end{array}$ & $\begin{array}{l}\text { Carcinogen } \\
\text { Risk }\end{array}$ \\
\hline \multicolumn{6}{|c|}{ 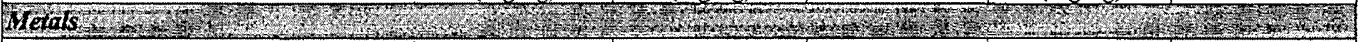 } \\
\hline Boron & 1.5 & 16,000 & $9.4 \mathrm{E}-05$ & $-\ldots$ & -- \\
\hline Selenium & 3.0 & 400 & $7.5 \mathrm{E}-03$ & -- & $\ldots$ \\
\hline \multicolumn{6}{|c|}{ 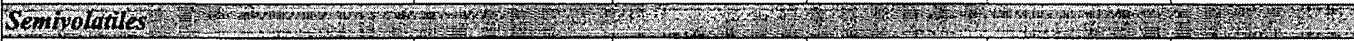 } \\
\hline Anthracene & 0.047 & 24,000 & $2.0 \mathrm{E}-06$ & -- & -. \\
\hline Benzo(a)anthracene & 0.29 & $\ldots$ & -- & 1.37 & $2.1 \mathrm{E}-07$ \\
\hline Benzo(a)pyrene & 0.18 & $\cdots$ & $\ldots$ & $0.33^{\mathrm{c}}$ & $5.5 \mathrm{E}-07$ \\
\hline Benzo(b)fluoranthene & 0.22 & - & - & 1.37 & $1.6 \mathrm{E}-07$ \\
\hline Benzo(k)fluoranthene & 0.18 & - & - & 13.7 & $1.3 \mathrm{E}-08$ \\
\hline Butylbenzylphthalate & 0.028 & 16,000 & $1.8 \mathrm{E}-06$ & - & - \\
\hline Chrysene & 0.34 & - & -- & 137 & $2.5 \mathrm{E}-09$ \\
\hline Dibenzo(a,h)anthracene & 0.061 & - & - & $0.33^{c}$ & $1.8 \mathrm{E}-07$ \\
\hline Fluoranthene & 0.69 & 3,200 & $2.2 \mathrm{E}-04$ & - & - \\
\hline Indeno $(1,2,3-\mathrm{cd})$ pyrene & 0.11 & - & - & 1.37 & $8.0 \mathrm{E}-08$ \\
\hline Phenanthrene & 0.34 & 24,000 & $1.4 \mathrm{E}-05$ & - & -. \\
\hline Pyrene & 0.51 & 2,400 & $2.1 \mathrm{E}-04$ & -- & $\ldots$ \\
\hline \multicolumn{6}{|c|}{ 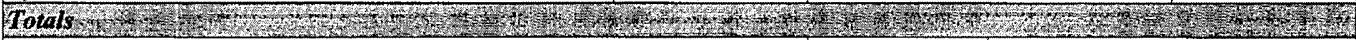 } \\
\hline \multicolumn{3}{|c|}{ Cumulative Hazard Quotient: } & $8.0 \mathrm{E}-03$ & & \\
\hline \multicolumn{5}{|l|}{ Cumulative Excess Cancer Risk: } & $2.2 \mathrm{E}-06$ \\
\hline
\end{tabular}

Notes:

$\mathrm{RAG}=$ remedial action goal

.. = not applicable

$a=$ From WCH (2005).

${ }^{b}=$ Value obtained from Washington Administrative Code (WAC) 173-340-740(3), Method B, 1996.

${ }^{c}=$ Total carcinogenic risk calculated using the cleanup level of $0.137 \mathrm{mg} / \mathrm{kg}$ instead of the required detection limit, per WAC 173-340-740(3), Method B, 1996. Individual carcinogenic risk calculated using the required detection limit.

\section{CONCLUSION:}

This calculation demonstrates that the 600-233 waste site meets the requirements for the hazard quotients and carcinogenic (excess cancer) risk as identified in the RDR/RAWP (DOE-RL 2005). 


\section{APPENDIX E}

\section{COMPLIANCE OF THE 600-233 DIESEL PIPES SITE WITH} WASHINGTON ADMINISTRATIVE CODE 173-360

(2 Pages) 


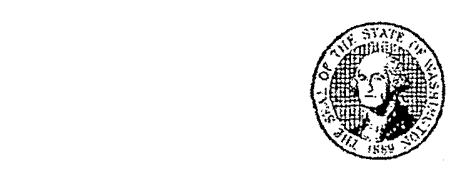

STATE OF WASHINCTON

\section{DEPARTMENT OF ECOLOGY \\ 3100 Purt of Bcntun Blvd • Richland, WA $94352 \cdot(509) 372-7950$}

April 25, 2005

Mr. Keith A. KJein

Richland Operations Office

United States Department of Energy

P.O. Box 550, MSN: A7-50

Richland, Washington 99352

Dear Mr. Klein:

Re: Compliance of the 600-233 Diesel Pipes Site with Washington Administrative Code $173-360$

Reference: November 11, 2004, E-Mail from Dean Strom to John Price

December 15, 2004, E-Mail and Fax (Sample Results) from Dean Strom to Dick Heggen

December 20, 2004, E-Mail from Dean Strom to John Price and Dick Heggen

February 1, 2005, Ecology Site Visit and Interview with Dean Strom, Resident Engineer in charge of the 600-233 Diesel Pipes Project

March 28, 2005, E-Mail from Dean Strom to Dick Heggen

(Disposition of Diesel Liquid)

Based on our review of information related to the 600-233 Diesel Pipe site, we determine that the 600-233 Diesel Pipes no longer pose a threat to human health or the environment. Therefore no further action is required for the 600-233 Diesel Pipes. This determination only applies to the 600-233 Diesel Pipes site described in the above correspondence. It does not apply to any other release or potential release at Hanford.

If you have any questions, please contact John Price at (509) 372-7921.

Sincerely,

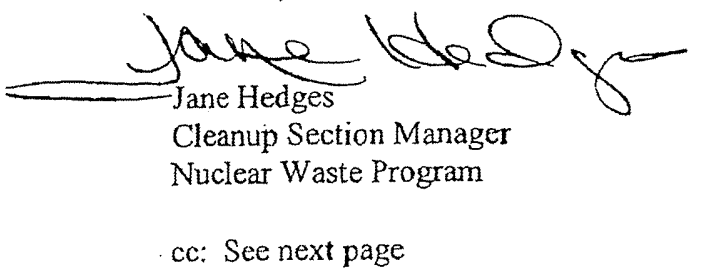


Mr. Keith A. Klein

April 25, 2005

Page 2

cc: Dennis Faulk, EPA

Kevin Bazzell, USDOE

Steve Burnum, USDOE

Steve Wisness, USDOE

Richard Carlson, BHI

Ella T. Feist, BHI

Dean Strom, BHI

Stuart Harris, CTUIR

Gabriel Bohnee, NPT

Russell Jim, YN

Todd Martin, HAB

Ken Niles, ODOE

John Price, Ecology

Administrative Record: $100-\mathrm{BC}-2$

Environmental Portal 